\title{
LEGAL STANDARDS GOVERNING INVESTMENT OF PENSION ASSETS FOR SOCIAL AND POLITICAL GOALS*
}

\author{
James D. Hutchinson $\uparrow$ and Charles G. Cole $\$$
}

\section{INTRODUCTION}

\section{A. The Scope of this Analysis}

It is not surprising that numerous interest groups are beginning to cast covetous eyes on the enormous amount of capital accumulated in private pension plans. Presently, private pension funds amount to more than $\$ 279$ billion. ${ }^{1}$ When public retirement systems are included, the amount exceeds $\$ 500$ billion. $^{2}$ It is projected that these totals will surpass $\$ 1.3$ trillion by 1986 and will constitute nearly half of the external capital raised by domestic corporations. ${ }^{3}$

While this enormous pool of capital is being aggregated, questions have arisen concerning the financial stability of some of the country's major public and private institutions, such as New York City and the Chrysler Corporation. In each of these cases, use of retirement-plan assets has been viewed as a possible remedy for the institution in distress. ${ }^{4}$ Other geographic areas or industries may look to employee benefit funds as a source of capital for future projects. These developments suggest that the question of what

- Many of the ideas in this Article were developed in a paper presented at a forum of the Employee Benefits Research Institute in Washington, D.C. on December 6, 1979.

$\uparrow$ Partner in the Washington, D.C., law firm of Steptoe \& Johnson. B.A. 1965, Dickinson College; J.D. 1968, Villanova University. Member, District of Columbia Bar and Pennsylvania Bar.

It Associate in the Washington, D.C., law firm of Steptoe \& Johnson. B.A. 1973, Yale College; J.D. 1976, Harvard University. Member, District of Columbia Bar.

1 U.S. Securrties and Exchange Commission, Statistical Buluetin, Vor. 37, No. 5 , at 8 (1978).

2 Id.

3 Stafy of the Subcomm. on Antitrust, Monopoly and Bustness Rughts of the Senate Comm. of the Judiciary, 96Th Cong., Ist Sess., Beneficiary Participation in Private Pension Plans 1 (Comm. Print 1979) [hereinafter cited as Staff Report].

4 See Withers v. Teachers' Retirement Sys. of N.Y., 447 F. Supp. 1248 (S.D. N.Y. 1978), aff'd, 595 F.2d 1210 (2d Cir. 1979) (rebuffing challenge to investment of public-employee pension funds in New York bonds to ameliorate the City's fiscal problems); note 14 infra \& accompanying text (discussing Chrysler-UAW settlement). 
social purposes should be accomplished through the use of public and private pension capital will continue to be important in the years ahead.

This Article addresses a narrow, yet important, aspect of the problem: the legal standards applicable to the investment of pension trust capital, particularly in the private sector. ${ }^{5}$ The Article focuses on the capital collected in private retirement-plan trusts presently subject to a federal regulatory scheme contained primarily in the Employee Retirement Income Security Act of 1974 (ERISA), ${ }^{6}$ the Internal Revenue Code, ${ }^{7}$ and the Labor-Management Relations (Taft-Hartley) Act. ${ }^{8}$ One unifying factor making such capital pools more homogeneous than endowments and personal trusts is that they already are subject to a federal legal standard with an articulated social purpose-the adequate financing of retirement benefits. ${ }^{9}$

The analysis concentrates on present legal standards, including those that have received little scrutiny in the social-investing debate, in the hope that this will assist individuals studying the investment policies of pension plans in their evaluation of issues that may arise in this setting. Others may profitably develop the social, political, and economic arguments concerning what the law should be in this area. ${ }^{10}$

5 Public plans raise additional difficult issues, such as the varying standards of care applicable to fiduciaries of these plans, the possibility of conflicts of interest presented by public officials serving as fiduciaries, and constitutional protections for government-employee pension interests. See generally Withers v. Teachers' Retirement Sys. of N.Y., 447 F. Supp. 1248 (S.D.N.Y. 1978), aff'd, 595 F.2d 1210 (2d Cir. 1979); General Accounting Office, Funding of State and Local Governament Penston Plans: A National Problem, HRD-79-66 (1979); Note, Public Employee Pensions in Times of Fiscal Distress, 90 Harv. L. Rev. 992 (1977).

An analysis of federal and state laws that affect the investment of assets held by university endowment funds, private foundations, and personal trusts will be left for another setting. See, e.g., UNIFORM MANAGEMENT of Instirutronar Funds AcT (approved in 1972 and since adopted by 25 states). See generally Ravikoff \& Curzan, Social Responsibility in Investment Policy and the Prudent Man Rule, 68 CAIIF. L. REv. 518 (1980) [hereinafter cited as Ravikoff].

$6 \$ \$ 2-4082,29$ U.S.C. $\$ \$ 1001-1381$ (1976).

7 I.R.C. $\$ \$ 401-415,501-504$.

$8 \$ 1-303,29$ U.S.C. $\$ \$ 141-187$ (1976).

9 See ERISA, \$2, 29 U.S.C. \$1001 (1976); note 129 infra.

10 The President's Commission on Pension Policy is presently studying this issue. See Mares, The Use of Pension Fund Capital: Its Social and Economic Implications-Some Background Issues 1 (Nov. 19, 1979) (working paper for President's Commission on Pension Policy). Congress has also explored this issue in recent hearings. See StafF Report, supra note 3 . The Wisconsin Center for Public Policy has also recently obtained a study on the impact of local investing of plan assets. See Scott, Study Weighs "Social" Investment Risk, Pensions \& INVESTMENTs, Oct. 8, 1979, at 3. 
The Article's analysis proceeds in three distinct phases. Following the introductory comments and definition of social investing, part II introduces the applicable law. Part III then analyzes the impact on social investing of each of ERISA's separate fiduciary rules. ${ }^{17}$ This analysis is followed by a discussion in part IV of the prospects for litigation and the practical consequences of that environment for social investing. Part $V$ both summarizes the conclusions of the article and applies its framework to two social-investing problems frequently discussed in the literature.

\section{B. The Genesis of the Issue}

Much of the current debate on "social investment" of pension assets implies that this issue is of recent vintage. And there has been a recent flurry of activity including the widely quoted work of Messrs. Barber and Rifkin, ${ }^{12}$ legislation introduced in recent sessions of Congress, ${ }^{13}$ and the pension investment provisions in the

11 Subsection A of part III sets out the basic structure of the ERISA fiduciary rules. The first of those key standards is that fiduciaries are required to act prudently. See ERISA, $\$ 404(\mathrm{a})(\mathrm{I})(\mathrm{B}), 29$ U.S.C. $\$ 1104(\mathrm{a})(1)(\mathrm{B})(1976)$; 29 C.F.R. $\$ 2550.404 \mathrm{a}-1$ (1979); notes 74-98 infra \& accompanying text. It is in this setting that the fiduciary examines considerations of risk, return, liquidity, and diversification to ensure that the proposed investment makes sound financial sense for the plan. See notes 77-79 infra \& accompanying text.

A second, distinct test emanates from common-law notions of loyalty that require a trustee to act in the best interests of the beneficiaries rather than those of himself or third parties. See notes 34-38 infra \& accompanying text. Similarly, ERISA $\$ 404(a)(1)$ instructs the fiduciary to act "solely in the interest of the participants and beneficiaries" of the plan. 29 U.S.C. $\$ 1104(a)(1)(1976)$. See 44 Fed. Reg. 37,222 n.2 (1979); notes 99-147 infra \& accompanying text.

ERISA's third set of standards-which will be considered in subsections $D$, $E$, and F of part III-might be characterized as "structural" prohibitions because they preclude certain investment policies independent of the investment's prudence or fairness. These standards include prohibitions against transactions involving a "party in interest," see ERISA, $\$ 406,29$ U.S.C. $\$ 1106$ (1976); notes 181-206 infra \& accompanying text, regulation of transactions involving employer securities or employer real property, see ERISA, $\$ 407,29$ U.S.C. $\$ 1107$ (1976), and the requirement that every transaction be executed "in accordance with the documents and instruments governing the plan," ERISA, $\$ 404(\mathrm{a})(1)(D), 29$ U.S.C. $\$ 1104$ (a) (1)(D) (1976); see notes 157-80 infra \& accompanying text.

12 J. Rufkun \& R. Barber, The North Wril Rise Agan: Pensions, Polttics AND POWER IN THE 1980's (1978).

13 E.g., Revenue Act of 1978, \$143, P.L. 95-600, 92 Stat. 2763, 2796 (codified at I.R.C. $\$ 401(\mathrm{a})(22)$ ) (requiring pass through of voting rights in employer stock where defined contribution plan owns more than $10 \%$ of employer stock not publicly traded); S. 1745, 95th Cong., 1st Sess., 123 Cong. Rec. 510, 385 (daily ed. June 22, 1977) (remarks of Sen. Mclntyre) (size of business alone will not disqualify investment under ERISA's prudence rule); S. 285, 95th Cong., Ist Sess., 123 Conc. REc. 1457 (1977) (plan may invest up to two percent of assets in small businesses without regard to prudent-man rule); H.R. 12666, 95th Cong., 2d Sess., Hearings on H.R. 12666 Before the Subcomm. on Capital, Investment and Business Opportunities of the House Comm. on Small Business, 95th Cong., 2d Sess. 2-3 (1978) (modifying ERISA prudence rule to permit investment of up to five percent of plan assets in small businesses). 
1979 Chrysler/U.A.W. contract settlement. ${ }^{14}$ A recent study on the investments of major public and private plans has also stimulated discussion by identifying 99 "target companies" with allegedly deficient social performance. ${ }^{15}$

This aura of novelty tends to obscure more than a decade of debate on the problem in Congress. In 1967, for example, the AFL-GIO Annual Convention adopted a "Policy Resolution on Proposals for Federal Legislation to Regulate Health, Welfare, Pension and Profit Sharing Plans" favoring the investment of pension funds in "socially useful projects." 16 An AFL-CIO representative presented this position in congressional hearings on proposed federal fiduciary standards for private plans in December 1969.17 Again, in congressional hearings held in 1970, Walter Reuther of the U.A.W. made an eloquent plea for flexibility in the law so that trustees could invest in "high social priority projects." 18 Similarly, in hearings in 1973, Ralph Nader advanced a complex proposal which included a provision permitting investment of up to ten percent of the assets of a pension fund in "special allowance investments" designed to reduce the housing, medical, and consumer expenses of retirees. ${ }^{19}$ Indeed, several early versions of pen-

14 The agreement is reported to have created an investment advisory board consisting of equal numbers of union and management members. - Up to $10 \%$ of new contributions would be invested in residential mortgages in areas where UAW members live, and in nursing homes, nursery schools, federally qualified health maintenance organizations, and other socially desirable projects. In addition, the union would have the right to recommend that pension trustees not invest in up to five companies that conduct business in South Africa. See [1979] PENs. ReP. (BNA), Oct. 29, 1979 (No. 263), at A-28 to A-29. The Control Data Corporation also has recently instructed its investment managers to consider social criteria in investment decisions. Scott, Control Data Instructs Fund Managers To Use "Socially Responsible" Criteria, Pensions \& Investalents, Aug. 13, 1979, at 1.

15 Corporate Data Exchange, Inc., Pension Invesmants: A Soctal. Audit (1979). For a vigorous critique of the criteria used to measure social performance in that study, see Schotland, Divergent Investment for Pension Funds, in EMPLOyEE Benefits Research Institute, Should Pension Assets Be Managed For Soctal/ Polrtical PuRposes? 105, 149-59 (D. Salisbury ed. 1980) [hereinafter cited as EBRI]. We do not here attempt to resolve this controversy over what conduct is "socially responsible" or how the degree of social responsibility practiced by a company should be measured.

16 Private Welfare and Pension Plan Legislation: Hearings on H.R. 1045, H.R. 1046, and H.R. 16462 Before the General Subcomm. on Labor of the House Comm. on Education and Labor, 91st Cong., Ist \& 2d Sess. 102-04 (1969-1970) (statement of Andrew J. Biemiller) [hereinafter cited as Private Welfare Hearings].

17 Id. 104-12.

18 Id. 186 (statement of Walter Reuther); see id. 194, 197.

10 Welfare and Pension Plan Legislation: Hearings on H.R. 2 and H.R. 462 Before the General Subcomm. on Labor of the House Comm. on Education and Labor, 93d Cong., 1st Sess. (pt. 1) 260, 271-72, 292-93 (1973) (statement of Ralph Nader and Karen Ferguson) [hereinafter cited as Pension Plan Hearings]. 
sion reform legislation authorized plan provisions permitting socially desirable investments without regard to prudence. ${ }^{20}$

The final language of ERISA's fiduciary rules, discussed below, ${ }^{21}$ was shaped in the context of this early activity. Thus, the courts will not be writing on a clean slate when they undertake to resolve questions concerning the permissibility of socially desirable investments. ${ }^{22}$ It seems likely that the judiciary will act upon the premise that the legislature has considered this issue and provided an answer in ERISA's fiduciary standards.

\section{Defining "Social Investing"}

The issue of social investing has proven elusive of analysis, in part because of its protean character. Depending on the context, social investing may take different, sometimes philosophically inconsistent, forms. A policy of social investment may be designed to benefit the participants incidentally by improving the community in which they live, or it may be designed to ameliorate, some regional, national, or even international problem. A socialinvestment program may involve a selfless sacrifice of the participants' interests in order to aid some other, less fortunate segment of society, or it may be part of a calculated strategy to enhance the political and economic strength of the participants.

The techniques for implementing a policy of social investing may also vary widely: from a policy of excluding future investments in particular companies, to the affirmative selection of certain preferred investments, to the divestiture of undesirable investments. In each of these situations, moreover, the relative weight given to economic and social factors may be different: social considerations may dictate investment policy, or they may be invoked only as a guide when all other characteristics are comparable.

Most of the diverse practices discussed in the context of "social investing" can be classified within one of three basic categories: (1) totally neutral investment policies; (2) socially sensitive investment policies; or (3) socially dictated investment policies.

"Totally neutral investment policies" focus solely on the financial aspects of investment alternatives. Fiduciaries would analyze the traditional investment considerations, such as the plan characteristics (design, funding, etc.), risk/return considerations,

20 E.g., H.R. 16462, 91st Cong., 2d Sess., 116 Cong. Rec. 7453 (1970).

21 See part III infra.

22 For a more complete discussion of the legislative history of this aspect of ERISA, see notes 131-41 infra \& accompanying text. 
liquidity, and diversification. ${ }^{23}$ Within this frame of reference, it may be that labor-relations practices, compliance with environmental or safety standards, or other policies could affect the financial stability and profitability of a company whose securities are being analyzed. If the fiduciary performing the financial analysis of the investment activity has a sound empirical basis for considering these factors, then their use is defensible on purely financial grounds.24 The fiduciary does not override basic financial investment considerations for the sake of a social objective, nor does he temper judgments on comparable alternatives by focusing on noninvestment factors. The question of "social investing" never arises in this setting, and we need not confuse the legal analysis applicable to "social investing" by belaboring such practices.

"Socially sensitive investment policies" include those investment practices in which the investing fiduciary analyzes traditional investment considerations such as plan characteristics, risk/return factors, liquidity, and diversification. Once this analysis is completed, however, the fiduciary then selects among financially comparable investment alternatives by considering other factors. As the following analysis suggests, so long as the fiduciary has not decided to sacrifice comparability of safety, return, diversification, or marketability in order to employ noninvestment considerations, he has discharged his responsibility under the "prudence" standard. ${ }^{25}$

There remains the question, however, whether the investment is being undertaken "solely in the interest" of plan participants and beneficiaries. ${ }^{26}$ It is at this point that certain "socially sensitive" investment policies that consider nonfinancial factors may pass legal muster, while others may not. A review of the legislative history of ERISA, in addition to recent legislative and judicial activity, suggests that certain policies that are intended to serve the interests of plan participants, in their capacity as participants, may be employed. On the other hand, policies that cannot be related in some plausible fashion to the primary interests of

23 See 29 C.F.R. $\$ 2550.404 a-1$ (1979).

24 A recent Senate staff report concluded:

In cases where social factors affect a company's profitability prospects, such criteria may be considered in the profitability analysis itself. Profitability may be adversely affected by such factors as instability of a company's labor relations and an unstable political situation in the country in which an investment is located or with which the company does business.

StAFF Report, supra note 3, at 1-2.

25 See text following note 98 infra.

26 See notes 99-147 infra \& accompanying text. 
plan participants, but instead serve the interests of the employer, union, or third parties, may well violate this standard of loyalty or the more specific rules that prohibit dealings with parties directly or indirectly related to the plan..$^{27}$

"Socially dictated investment policies" are those investment practices and policies which either (1) permit the sacrifice of safety, return, diversification, or marketability; or (2) are undertaken to serve some objective that cannot be related to the interests of plan participants and beneficiaries in their capacity as such. When a plan fiduciary sacrifices traditional investment quality, he faces the substantial risk of violating the prudence standard. ${ }^{28}$ Likewise, if a fiduciary acts to further his own interests or those of third parties, he will be in violation of the loyalty standard..$^{29}$ Given the present state of the law governing the investment of plan assets, plan fiduciaries would be ill-advised to direct or permit either kind of activity.

\section{Applicable Law}

\section{A. Pre-ERISA Sources of Law}

Prior to the enactment of ERISA, there were three principal sources of law governing investment decisions of a fiduciary managing an employee benefit plan: trust law, the Internal Revenue Code, and the Taft-Hartley Act.

All plans employing the trust device were governed by statelaw fiduciary principles generally applicable to trusts. The most familiar of these was the prudent-man rule: in the absence of a contrary direction in the trust, the trustee is under a duty to "make such investments and only such investments as a prudent man would make of his own property having in view the preservation of the estate and the amount and regularity of the income to be derived." ${ }^{30}$ While an assurance of "reasonable" income is one permissible objective under the common law, ${ }^{31}$ most courts applying

27 See notes $99-156$ \& notes 181-206 infra \& accompanying text.

28 See, e.g., note 94 infra \& accompanying text.

29 See notes 99-156 \& notes 181-206 infra \& accompanying text.

30 Restatiement (Second) of Trusts $\$ 227$ (1959). See generally G.G. Bogert \& G.T. Bogert, THE Law of Trusts aND Trustees $\$ 612$, at 407-11 (2d ed. 1960 \& Supp. 1979) [hereinafter cited as BogenT]; Fleming, Prudent Investments: The Varying Standards of Prudence, 12 ReAL Prop. Prob. \& Tr. J. 243 (1977). A few states still limit the percentage of assets that may be invested under the prudent-man rule and prescribe a "Tegal list" of permissible investments. Id. 410 \& n.20 ( 2 d ed. 1960).

31 Restatement (Second) of Trusts $\$ 227$, Comment e (1959). 
the common-law rule take the possibility of capital loss as the principal measure of the riskiness of an investment, ${ }^{32}$ and tend to focus on the prudence of the individual investment rather than on the wisdom of the investment within the context of the entire portfolio. ${ }^{33}$

The common law also imposed on the fiduciary of an employee benefit trust a duty of loyalty to the beneficiaries. ${ }^{34}$ In order to prevent a conflict of interest, the fiduciary was prohibited from entering into transactions with the trust ${ }^{35}$ or from competing with the trust res. ${ }^{36}$ In addition to such specific proscriptions of selfdealing and conflict of interest, the trustee was "enjoined to administer the trust solely in the interest of the beneficiary." 37 The terms of the trust, however, could sometimes authorize the fiduciary to do what would otherwise be a breach of his duty of loyalty to the beneficiaries. ${ }^{38}$

Second, certain provisions of the Internal Revenue Code reinforce common-law trust principles. In order to qualify for taxexempt status under the Code, ${ }^{39}$ the employer's plan must be maintained "for the exclusive benefit of his employees or their beneficiaries," 40 and the trust instrument must make it "impos-

32 See Note, Fiduciary Standards and the Prudent Man Rule Under the Employment [sic] Retirement Income Security Act of 1974, 88 HARv. L. REv. 960, 966-67 (1975) [hereinafter cited as Fiduciary Standards]; Note, The Regulation of Risky Investments, 83 HARv. L. REv. 603, 616-17 (1970).

33 See, e.g., Withers v. Teachers' Retirement Sys. of N.Y., 447 F. Supp. 1248, 1254-55 (S.D.N.Y. 1978), affd, 595 F.2d 1210 (2d Cir. 1979); Bank of N.Y. v. Spitzer, 35 N.Y.2d 512, 517, 323 N.E.2d 700, 703, 364 N.Y.S.2d 164, 168 (1974); McKechnie v. Springfield, 311 Mass. 406, 414, 41 N.E.2d 557, 561 (1942); REstatement (Second) of Trusts $\$ 213$ (1959).

34 See 2 A. ScotT, THE LAw OF TRUSTs $\$ 170$ (3d ed. 1967) [hereinafter cited as Scort on Trusts].

35 Restatement (SeCOND) of Thusts $\$ 170$, Comments b, c, \& h (1959).

36 Id. Comment p.

37 Id. $\$ 170$. Although the common-law duty of loyalty clearly precludes the trustee from taking any action for his own benefit, there is increasing support from commentators (but not the courts) for the view that an institutional trustee may follow an investment policy that benefits the community as a whole as well as the specific beneficiaries. See 3 Scotr on Trusts, supra note 34, at $\$ 227.17$ (Supp. 1980).

382 Scotr on Trusts, supra note 34 , at $\$ 170.9$ (3d ed. 1967). On grounds of public policy, some state statutes refuse to permit the terms of the trust to legalize more dangerous acts of disloyalty. See BoGERT, supra note 30 , at $\S 543(\mathrm{u})$, at $377-78$ (rev. $2 \mathrm{~d}$ ed. 1978).

39 When a plan has qualified for such status, the employer may immediately deduct his contributions as ordinary and necessary business expenses, I.R.C. $\S 404$ (a), the plan need not ordinarily pay tax on its investment income, id. $\$ 501(\mathrm{a})$, and the participant may defer payment of tax until the receipt of benefits. Id. $\$ \$ 402(a)(1), 403(a)(1)$.

$40 I d . \$ 401(a)$. 
sible . . . for any part of the corpus or income to be . . . used for, or diverted to, purposes other than for the exclusive benefit of his employees or their beneficiaries." 41

Although the exclusive-benefit rule of the Internal Revenue Code obviously applies to the investment of plan assets, historically it has not been a stringent constraint. ${ }^{42}$ The Internal Revenue Service and the courts have been understandably reluctant to enforce the rule strictly by disqualifying plans and thereby depriving employees of the tax benefits to which they would otherwise be entitled.43 The Internal Revenue Service has interpreted the exclusive-benefit rule to permit some collateral benefit to other persons, so long as the investments have the primary purpose of benefiting employees or their beneficiaries. ${ }^{44}$ Courts have agreed that incidental benefit to a third party is not sufficient to justify disqualification of a plan..$^{45}$

A third, pre-ERISA source of legal control on the operations of employee benefit plans was section 302 (c) (5) of the Taft-Hartley

41 Id. $\oint 401$ (a)(2). A plan will be considered not to be for the exclusive benefit of employees if it is a subterfuge for the distribution of profits to shareholders or if it discriminates in favor of officers, shareholders, or highly compensated employees. Id. $\$ 401(\mathrm{a})(4) ; 26$ C.F.R. $\$ 1.401-1(\mathrm{~b})(3)$ (1979). In certain circumstances, however, it may be possible for a plan to return to an employer excess contributions based on a mistake of fact, see ERISA, $\$ 403$ (c)(2)(A), 29 U.S.C. $\$ 1103(\mathrm{c})(2)(\mathrm{A})(1976)$, or the residual assets of the plan after all obligations have been paid upon termination, see ERISA, $\$ 403(c)(1), 29$ U.S.C. $\$ 1103$ (c)(1) (1976), without violating the strictures of I.R.C. $\$ 401$ (a)(2).

42 The implementing regulations authorize the purchase of any investment permitted by the trust agreement to the extent allowed by local law. 26 C.F.R. $\$ 1.401-l(b)(5)(i)(1979)$.

43 Time Oil Co. v. Commissioner, 258 F.2d 237, 238 (9th Cir. 1958); S. ReP. No. 93-383, 93d Cong., 1st Sess. 3-4, 18 (1973), reprinted in [1974] U.S. CoDE Cong. \& AD. News 4890, 4892, 4903, also reprinted in 1 Subcomm. on Labor of the Senate Comar. on Labor and Public Welfare, 94ta Cong., 20 Sess., leg-

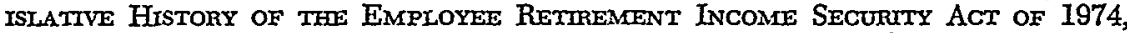
at 1063, 1071-72, 1086 (Comm. Print 1973) [hereinafter cited as ERISA LEg. Hust.1; Herbert, Investment Regulation and Conflicts of Interest in EmployerManaged Pension Plans, 17 B.C. Indus. \& CoM. L. Rev. 127, 140-41 (1976).

44 E.g., Rev. Rul. 69-494, 1969-2 C.B. 88. The Service has taken the position that other parties-including the employer-may benefit from plan investments so long as four investment requisites are met:

These requisites are: ( 1 ) the cost must not exceed fair market value at time of purchase; (2) a fair return commensurate with the prevailing rate must be provided; (3) sufficient liquidity must be maintained to permit distributions in accordance with the terms of the plan; and (4) the safeguards and diversity that a prudent investor would adhere to must be present.

Id. Although this administrative interpretation of the statute is entitled to some deference, see Central Motor Co. v. United States, 583 F.2d 470, 490 (10th Cir. 1978), it has never been explicitly sustained by the courts. See Shelby U.S. Distribs., Inc. v. Commissioner, 71 T.C. 874 (1979).

45 See Shelby U.S. Distribs., Inc. v. Commissioner, 71 T.C. 874, 885 (1979); Feroleto Steel Co. v. Commissioner, 69 T.C. 97, 113 (1977). 
Act, ${ }^{46}$ which applies only to plans established jointly by a union and one or more employers. This provision permits employer contributions to the trust fund only if the trust meets certain conditions designed to prevent diversion of the funds by union officers to themselves or to the union. ${ }^{47}$ The Act also requires that the trust fund be established "for the sole and exclusive benefit of the employees of such employer, and their families and dependents." 48

Most federal courts have interpreted section 302 to govern only the structure of covered plans and not also to grant jurisdiction to the federal courts to adjudicate individual violations of fiduciary standards. ${ }^{49}$ Nevertheless, the courts have found the "sole and exclusive benefit" rule a sufficient basis for invalidating those general rules or practices of trust administration that appeared designed to benefit persons other than the employees. ${ }^{50}$ For example, allegations that a break-in-service provision of a pension plan was intended primarily to benefit the union have been held to state a claim under section 302(c)(5)..$^{51}$ Although section 302 (c) (5) retains some vitality as a means to challenge certain practices of jointly administered trusts, ${ }^{52}$ its utility has been overshadowed by the more pervasive provisions of ERISA. ${ }^{53}$

\section{B. ERISA}

Congressional enactment of ERISA followed nearly a decade of review of the existing legal framework for the regulation of em-

4829 U.S.C. $\$ 186(c)(5)$ (1976).

47 For example, there must be a written agreement detailing the basis on which payments are to be made, and the fund must be jointly administered by equal numbers of employer and union representatives. Taft-Hartley Act, $\$ 302$ (c) (5)(B), 29 U.S.C. $\$ 186$ (c)(5)(B) (1976). The Act permits the mutually agreeable addition of neutral persons. Id.

48 Id., $\$ 302$ (c)(5)(A), 29 U.S.C. $\$ 186(c)(5)(A)$ (1976).

49 E.g., Haley v. Palatnik, 509 F.2d 1038, 1040-41 (2d Cir. 1975); Snider v. All State Adm'rs, Inc., 481 F.2d 387, 390 (5th Cir. 1973), cert. denied, 415 U.S. 957 (1974); Bowers v. Ulpiano Casal, Inc., 393 F.2d 421, 424-26 (1st Cir. 1968).

50 E.g., Souza v. Scalone, 64 F.R.D. 654 (N.D. Cal. 1974), vacated on other grounds, 563 F.2d 385 (9th Cir. 1977); Lugo v. Employees Retirement Fund of the Illumination Prods. Indus., 366 F. Supp. 99 (E.D.N.Y. 1973); Insley v. Joyce, 330 F. Supp. 1228 (N.D. Ill. 1971).

51 E.g., Insley v. Joyce, 330 F. Supp. 1228 (N.D. Mll. 1971). Even under this provision, however, an indirect or incidental benefit to the union or the employer would probably not be prohibited by the statute. See Lugo v. Employees Retirement Fund of the Illumination Prods. Indus., 388 F. Supp. 997, 1001 (E.D.N.Y. 1975), aff d, 529 F.2d 251 (2d Cir.), cert. denied, 429 U.S. 826 (1976); Culinary Workers and Bartenders Local 596 Health and Welfare Trust v. Gateway Cafe, 91 Wash. 2d 353, 一, 588 P.2d 1334, 1340 (1979).

62 ERISA, \$ 514(d), 29 U.S.C. \$1144(d) (1976) (saving all federal laws from preemption).

53 See Cutaiar v. Marshall, 590 F.2d 523, 530 (3d Cir. 1979). 
ployee benefit plans. ERISA preempts-as of January 1, 1975all state laws "insofar as they may now or hereafter relate to any employee benefit plan" covered by the statute, ${ }^{54}$ thus precluding the application of state fiduciary principles to investment decisions made after that date. ${ }^{55}$ Although the Internal Revenue Code requirements remain in effect, the conference report to ERISA states that a fiduciary satisfying the ERISA standards for investment will be deemed to be in compliance with those aspects of the exclusive-benefit requirements of the Internal Revenue Code.56 Similarly, it appears that satisfaction of the more specific ERISA standards would satisfy the "exclusive benefit of the employees" rule of the Taft-Hartley Act.57

Thus, questions whether various forms of social investing are permissible for private-sector employee benefit plans must be determined by reference to the fiduciary standards of ERISA. ${ }^{58}$ Prior decisional law remains relevant, however, because Congress, in fashioning ERISA, drew language and principles from the earlier bodies of law.59 Proper interpretations of the statute will draw on points of both similarity and difference between traditional fiduciary standards and ERISA's provisions.

In the hearings preceding ERISA's passage, Congress studied the investment practices of employee benefit plans under the existing legal framework. The hearings exposed many abuses, including

54 ERISA, $\$ 514($ a), 29 U.S.C. $\$ 1144$ (a) (1976).

55 See Marshall v. Chase Manhattan Bank, 558 F.2d 680 (2d Cir. 1977). For a more comprehensive discussion of the preemptive effect of ERISA, see generally Hutchinson \& Ifshin, Federal Preemption of State Law Under the Employee Retirement Security Act of 1974, 46 U. Crr. L. Rev. 23 (1978); Turza \& Halloway, Preemption of State Laws Under the Employee Retirement Income Security Act of 1974, 28 CATH. U. L. REv. 163 (1979).

56 H.R. Rgp. No. 93-1280, 93d Cong., 2d Sess. 302 [hereinafter cited as CoNference Report], reprinted in [1974] U.S. Code Cong. \& Ad. News 5038, 5083, also reprinted in 3 ERISA I.EG. Hist., supra note 43 , at $4277,4569$.

57 Cutaiar v. Marshall, 590 F.2d 523, 528 (3d Cir. 1979).

58 ERISA does not cover plans maintained by state or local governments. See Feinstein v. Lewis, 477 F. Supp. 1256, 1259 (S.D.N.Y. 1979); ERISA, \$\$3(32), $4(\mathrm{~b})(1), 29$ U.S.C. $\$ \$ 1002(32) ; 1003(\mathrm{~b})$ (I) (1976). In 1978, Representatives Dent and Erlenborn, the chairman and ranking minority member of the House Labor Standards Subcommittee, introduced a proposed Public Employee Retirement Income Security Act (PERISA), H.R. 14138, 95th Cong., 2d Sess., 124 Conc. Rec. H10, 264 (daily ed. Sept. 20, 1978). This bill would have subjected fiduciaries for public plans to the same standards of fiduciary responsibility as apply to private plans under ERISA $\$ 404(\mathrm{a})(1)$, as well as adding certain prohibited transactions. See [1978] PENS. REP. (BNA), Sept. 25, 1978 (No. 207), at A-I5, R-19. Although this legislation was not enacted by the 95th Congress, there is continuing pressure to enact legislation protecting the interests of participants in public plans. See H.R. 6525, 96th Cong., 2d Sess., reported in [1980] Pens. ReP. (BNA), Feb. 2, 1980 (No. 278), at A-12.

59 See notes 30-53 supra \& accompanying text. 
excessive investments in employer stock, absence of diversification, and use of plan assets for the benefit of plan fiduciaries. ${ }^{60}$ The congressional committees concluded that the common-law emphasis on the intent of the grantor, which permitted deviations from sound investment practices, was inappropriate for employee benefit plans. ${ }^{61}$ The legislative history also pointed out the inadequacies of the existing legal procedures as means to control abuses and the need for a uniform fiduciary standard in the interstate context. ${ }^{62}$

These perceptions led directly to ERISA's new federal fiduciary standards and a concomitant system of enforcement. Under the statutory scheme, every plan must provide for one or more "named fiduciaries" having authority to control and manage the plan. ${ }^{63}$ Trustees named in the trust instrument, or appointed by a named fiduciary, have exclusive authority and discretion to manage plan assets, ${ }^{64}$ unless the plan expressly provides that the trustee will be subject to the direction of a named fiduciary ${ }^{e 5}$ or that investment authority will be delegated to an investment manager. ${ }^{68}$

All persons exercising discretionary authority or control with respect to the management of the plan or its assets fall within the Act's broad definition of "fiduciary." 67 The definition specifically embraces the plan's trustee, any investment managers to whom investment authority may have been delegated, and persons supplying

60 See Private Welfare Hearings, supra note 16, at 470-72 (app. to testimony of George Shultz).

61 H.R. ReP. No. 93-533, 93d Cong., 1st Sess. 12 (1973) [hereinafter cited as 1973 H.R. Rep.], reprinted in [1974] U.S. Code Cong. \& AD. NEws 4639, 4650, also reprinted in 2 ERISA LEG. HIsT., supra note 43, at 2348, 2359; S. Rep. No. 93-127, 93d Cong., Ist Sess. 29 (1973) [hereinafter cited as 1973 S. REP.], reprinted in [1974] U.S. CODE CoNG. \& AD. NEws 4838, 4865, also reprinted in 1 ERISA LEG. Hist., supra note 43 , at 587, 615.

62 See sources cited in note 61 supra.

63 ERISA, $\$ 402(a)(1), 29$ U.S.C. $\$ 1102(a)(1)$ (1976).

64 Id., $\$ 403(\mathrm{a}), 29$ U.S.C. $\$ 1103(\mathrm{a})(1976)$.

65 Id., $\$ 403(\mathrm{a})(1), 29$ U.S.C. $\$ 1103$ (a) (1) (1976).

66 Id., $\$ \S 402(\mathrm{c})(3), \quad 403(\mathrm{a})(2), 29$ U.S.C. $\$ \oint 1102(\mathrm{c})(3), \quad 1103(\mathrm{a})(2)$ (1976). See also id., $\$ 3(38), 29$ U.S.C. $\$ 1002(38)$ (1976) (definition of "investment manager"). part:

67 ERISA, $\$ 3(21)(A), 29$ U.S.C. $\$ 1002(21)$ (A) (1976) provides in relevant

[A] person is a fiduciary with respect to a plan to the extent (i) he exercises any discretionary authority or discretionary control respecting management of such plan or exercises any authority or control respecting management or disposition of its assets, (ii) he renders investment advice for a fee or other compensation, direct or indirect, with respect to any moneys or other property of such plan, or has any authority or responsibility to do so, or (iii) he has any discretionary authority or discretionary responsibility in the administration of such plan. 
investment advice for compensation. ${ }^{68}$ Thus, any person who directs the investment of plan assets-whether for social or financial purposes-is a fiduciary for purposes of ERISA.

An ERISA fiduciary is subject to both the general fiduciary standards of section $404^{69}$ and the specific "prohibited transaction" provisions of section $406 .{ }^{70}$ In addition, a fiduciary may be held liable for a knowing failure to prevent or remedy a breach of trust by a cofiduciary.71 Thus, although a trust may delegate responsibility for investment decisions to a qualified investment manager, a trustee with knowledge of a violation of the statute's fiduciary standards on the part of the manager may be held liable for failure to take appropriate action. In sum, ERISA casts a broad regulatory net over everyone with any responsibility for the management of the plan and may entangle them-like it or not-in the issue of social investing.

\section{Analysis of Social Investing Under ERISA}

\section{A. Structure of ERISA Section 404(a)}

The central provision regulating the investment activities of fiduciaries under ERISA is section 404 (a) of the statute. ${ }^{72}$ Two

68 Under the applicable regulations, a recommendation to purchase or sell a security is investment advice if the individual rendering it has discretion to make investment decisions or if he renders advice specialized for the plan with the understanding that his advice will be relied upon as a primary source of guidance in making investment decisions. 26 C.F.R. $\$ 54.4975-9$ (c)(1) (1979);29 C.F.R. $\$ 2510.3-21$ (c) (1) (1979).

69 ERISA, $\$ 404,29$ U.S.C. $\$ 1104$ (1976).

$70 \mathrm{Id}$., $\$ 406$, U.S.C. $\$ 1106$ (1976). The limitations imposed by this section are more fully discussed at notes 181-206 infra \& accompanying text. (1979).

71 ERISA, $\$ 405,29$ U.S.C. $\$ 1105$ (1976); 29 C.F.R. \$2509.75-5, FR-10

72 Subject to sections 403(c) and (d), 4042, and 4044, a fiduciary shall discharge his duties with respect to a plan solely in the interest of the participants and beneficiaries and-

(A) for the exclusive purpose of:

(i) providing benefits to participants and their beneficiaries; and

(ii) defraying reasonable expenses of administering the plan;

(B) with the care, skill, prudence, and diligence under the circumstances then prevailing that a prudent man acting in a like capacity and familiar with such matters would use in the conduct of an enterprise of a like character and with like aims;

(C) by diversifying the investments of the plan so as to minimize the risk of large losses, unless under the circumstances it is clearly prudent not to do so; and

(D) in accordance with the documents and instruments governing the plan insofar as such documents and instruments are consistent with the provisions of this subchapter.

ERISA, $\$ 404(a)(1), 29$ U.S.C. 1104 (a)(1) (1976). 
features of this provision should be noted at the outset. First, its standards apply to all of the duties for which a fiduciary is responsible under the plan. Thus, the prudence requirement constrains not only the selection of investments, but also the selection of an investment manager or advisor, the formulation of investment guidelines, the voting of shares held by the plan, and the ongoing monitoring of the plan's investment activity. These standards also apply to decisions that do not concern investments, such as operating policies. Indeed, the fiduciary standards of section $404(\mathrm{a})(\mathrm{l})$ even have application to conduct recommending, designing, or implementing amendments to the plan's structure. ${ }^{73}$ Second, fiduciary standards established by this provision are in the conjunctive; each must be satisfied by a proposed course of action. Thus, a prudent investment that violates the "solely in the interest of the participants and beneficiaries" standard of section 404(a) (1) does not comply with the statute. Similarly, activity that is prudent and solely in the interest of the participants and beneficiaries is impermissible if it is not also exclusively for the purpose of providing benefits and defraying the reasonable expenses of the plan as required by section $404(\mathrm{a})(1)(\mathrm{A})$ or has been undertaken in violation of plan documents, as proscribed by section 404(a) (1) (D). Because the fiduciary standards imposed by this provision are distinct, they are examined separately below.

\section{B. Social Investing Under the Federal Prudence and Diversification Rules}

\section{Prudence}

Much of the current debate on the propriety of social investing has focused on whether the prudence rule permits such investments. The prudence rule contained in section $404(\mathrm{a})(\mathrm{I})(\mathrm{B})$ provides no direct answer to this question. Whether a particular social investment is permissible under this section depends not only on the nature of the investment, but also on the needs of the plan and the characteristics of the remainder of the plan's portfolio.

Although section $404(\mathrm{a})(\mathrm{l})$ (B) is rooted in the prevailing common-law rule, ${ }^{74}$ the federal rule for covered employee benefit plans differs in several important respects. ${ }^{75}$ Under the federal

73 See Eaves v. Penn, 587 F.2d 453 (10th Cir. 1978); Winpisinger v. Aurora Corp. of Ill, 456 F. Supp. 559 (N.D. Ohio 1978).

74 See notes 30-33 supra \& accompanying text.

75 The preamble to the Department of Labor regulation explicating this subsection states that "[t]he 'prudence' rule in the Act sets forth a standard built upon, 
provision, the conduct of a fiduciary must be compared with that of other fiduciaries "acting in a like capacity and familiar with such matters ... in the conduct of an enterprise of like character and with like aims." 76 The legislative history makes clear that the purpose of this language was to fashion a flexible standard of prudence acknowledging the special purposes of employee benefit plans and the vast diversity among them. ${ }^{77}$

Federal regulations require the plan fiduciary to consider the funding objectives and cash-flow requirements of the plan in evaluating the rate of return and liquidity of a proposed investment. ${ }^{78}$ In general, an ERISA investment program must be designed with due regard for such varying plan characteristics as the nature and size of the plan, its tolerance for risk, funding status, liquidity needs, and contribution rates. ${ }^{79}$ Thus, the prudence of a proposed form of social investing cannot be evaluated in the abstract. The particular investment must be judged in light of the complete factual setting, including the plan's needs and characteristics.

The basic structure of the plan would be one relevant consideration in determining the propriety of a particular social investment. For example, in a defined benefit plan, the sponsoring employer or employers are responsible for making contributions ade-

but that should and does depart from, traditional trust law in certain respects." 44 Fed. Reg. 37,222 (1979). Accord, Marshall v. Teamsters Local 282 Pension Trust Fund, 458 F. Supp. 986, 990 (E.D.N.Y. 1978).

76 ERISA, $\$ 404$ (a) (I)(B), 29 U.S.C. $\$ 1104$ (a) (1)(B) (1976).

77 In hearings in 1970, Secretary of Labor George Shultz characterized similar language in H.R. 16462 as providing a standard with "a built in flexibility . . . which recognizes the vast diversity and other characteristics of private pension and welfare plans." Private Welfare Hearings, supra note 16, at 477 (statement of George Shultz). See generally Report, ERISA and the Investment Management and Brokerage Industries: Five Years Later, 35 Bus. LAw. 189, 238 \& n.35 (1979) [hereinafter cited as ERISA Report]. The American Bankers Association favored this language because it would give the trustees of employee benefit funds "sufficient latitude to invest the funds to the best advantage in current and future markets." Private Welfare Hearings, supra note 16, at 792 (statement of William F. Lackman).

7829 C.F.R. $\$ 2550.404 a-1$ (b) (2) (1979). The federal prudence standard also permits variations in the quality of investment-management expertise. The manager of a plan with assets of $\$ 50,000$ need not resort to the same investment techniques as would a fiduciary of a plan with assets of $\$ 50,000,000$. See 44 Fed. Reg. 37,224 (1979). On the other hand, the sliding scale used by the Labor Department suggests that a plan with sufficient funds to defray the expense of professional investment advice must be able to justify the prudence of its investments-including its social investments-with relatively sophisticated financial analysis. Id.

79 29 C.F.R. $\$ 2550.404 \mathrm{a}-1$ (b)(2) (1979). See Private Welfare Hearings, supra note 16, at 477 (statement of George Shultz), 521 (statement of Lawrence Silberman). For a discussion of the ERISA prudence standard, see generally Hutchinson, The Federal Prudent Man Rule Under ERISA, 22 VIIL. L. REv. 15 (1976); Klevan, Fiduciary Responsibility Under ERISA's Prudent Man Rule: What Are the Guideposts?, 44 J. TAx. 152 (1976); ERISA Report, supra note 77, at 23742; Fiduciary Standards, supra note 32. 
quate to provide a specified level of benefits to the participants. ${ }^{80}$ The sponsor thus bears the primary risk of capital loss or inadequate income to cover the plan's current obligations. In this situation, it would be less likely that a participant would challenge the conduct of a trustee or investment manager who, with the concurrence of the sponsors, followed a socially sensitive investment policy. Similarly, a socially dictated policy, though resulting in a technical violation of ERISA, would be less likely to provoke a challenge so long as the employer maintained the specified level of benefits. On the other hand, in a defined-contribution plan the funding obligation of the employer is limited to the amount specified in the plan documents, and the employees bear the direct investment risks. A socially dictated investment policy would not only be much harder to justify in this context, but also would be more likely to provoke litigation as participant benefits were lost. ${ }^{81}$

The nature of the plan is not the sole factor to be considered. Even in a defined benefit plan, the employer may not be able to meet its funding obligations. If the plan has a large unfunded liability, and the employer is not in good financial health, it might be imprudent to invest in socially desirable projects carrying a relatively high risk of loss. On the other hand, socially sensitive investing by a defined contribution plan may not be imprudent if a thorough analysis of the plan's portfolio demonstrates that the risk and return associated with the investment complement the remainder of the plan's portfolio in meeting the plan's investment objectives.

In this regard, a second important change wrought by ERISA in the prudence rule was a shift to a whole portfolio approach. Under the common law, the trustee could not defend his actions by showing that losses with respect to a particular investment were offset by gains on other investments or investment income. ${ }^{82}$ The common-law approach arose in part from the need in trust administration to resolve a basic conflict between the interests of income beneficiaries and remaindermen. This conflict does not arise in the same form, if indeed it arises at all, in the context of employee benefit plans. ${ }^{83}$

Recognizing the congressional directive to interpret the common law of trusts "bearing in mind the special nature and purpose

80 See International Bhd. of Teamsters v. Daniel, 439 U.S. 551, 554 n.3 (1979); ERISA, $\$ 3(35), 29$ U.S.C. $\$ 1002(35)$ (1976).

81 See notes 211 \& 212 infra \& accompanying text.

82 See note 33 supra \& accompanying text.

83 See 43 Fed. Reg. 17,481 (1978); Fiduciary Standards, supra note 32, at 967. 
of employee benefit plans," st the Department of Labor has issued regulations rejecting the compartmentalized common-law approach to analysis of the prudence of an investment. ${ }^{85}$ Under the regulations, the relative riskiness of an investment, standing alone, does not make the investment per se prudent or per se imprudent. Rather, the fiduciary must analyze the role that the investment plays within the entire portfolio. ${ }^{86}$ The fiduciary will be considered by the Department of Labor to be in compliance when he considers not only the possibility of capital gain or loss and probable investment income, ${ }^{87}$ but also such criteria as diversification, liquidity, current return relative to anticipated cash-flow requirements, and projected portfolio return relative to the plan's funding objectives. ${ }^{88}$ Generally stated, he must determine whether the individual investment or projected course of action is reasonably designed, as part of the portfolio, to further the overall purposes of the plan. ${ }^{89}$

This flexible interpretation of the prudent-man rule permits a larger universe of investments under the prudence rule of ERISA than under the common law.90 For example, the preamble to the Labor Department regulations states that investment in securities issued by a small or new company, which could be riskier than those of a "blue chip" company, may be entirely proper under the Act. ${ }^{91}$ The Department also has recognized the possibility that investments not producing current income-such as precious metal, objects of art, particular types of real estate investments, or certain stock option strategies-might play a legitimate role in a portfolio. ${ }^{92}$ This rationale would suggest that in appropriate circumstances other "nontraditional" investments, such as certain types of ven-

84 Conference Report, supta note 56, at 302, reprinted in [1974] U.S. Code Cong. \& AD. NEwS 5038, 5083, also reprinted in 3 ERISA LEG. Hist., supra note 43 , at 4277,4569 .

85 29 C.F.R. $\$ 2550.404 a-1$ (1979).

8644 Fed. Reg. 37,224-25 (1979). Safe harbor is provided to the fiduciary who gives "appropriate consideration" to the relevant facts and circumstances, including the role that an investment or investment course of action plays in the plan's portfolio. 29 C.F.R. $\$ 2550.404 a-1$ (b) (I) (1979).

8729 C.F.R. $\$ 2550.404 a-1$ (b)(2) (1979).

$88 \mathrm{Id}$.

$89 \mathrm{Id}$.

90 See 44 Fed. Reg. 37,225 (1979) (Department commentary).

91 Id. 37,222. Under the common law, the trustee must steer clear of investments in "new or untried" enterprises. See 3 Scotr on Trusts, supra note 34, at 1816.

9244 Fed. Reg. 37,224-25 (1979). 
ture capital or commodity futures investments, also might be permissible. ${ }^{93}$

Although the regulations do not refer in any way to the possibility of social investing, the "whole portfolio" approach adopted by the regulations may make it somewhat easier to defend the prudence of an investment undertaken in consideration of nonfinancial factors. For example, even though an investment in a pool of local mortgages may yield a lower rate of return than a projected return on corporate equities, the mortgage investment may be designed to help stabilize performance and provide diversification within a portfolio already holding large concentrations of equity securities. Similarly, investment in a new local business as part of an effort to revitalize a downtown area may not be imprudent given the size of the plan's portfolio, the riskiness of the other investments, the liquidity and income needs of the plan, and a determination that the local investment will play an appropriate part in meeting the plan's investment objectives.

The regulation, however, is not intended to create pools of unrestricted "mad money" that can be invested in any vehicle striking the fancy of the fiduciary with investment control. A fiduciary cannot ignore his obligation to evaluate a particular investment to ensure its consistency with plan characteristics and objectives merely because a favorable return on the total portfolio is assured by high returns on other plan investments. The preamble to the Labor Department regulations emphasizes that "a particular plan investment should [not] be deemed to be prudent solely by reason of the propriety of the aggregate risk/return characteristics of the plan's portfolio" and that "appropriate consideration of an investment to further the purposes of the plan must include consideration of the characteristics of the investment itself." 94

\section{Diversification}

Analysis of the role played by an investment within the plan's portfolio necessarily includes consideration whether the plan is adequately diversified. ERISA section $404(\mathrm{a})(\mathrm{l})(\mathrm{c})$ emphasizes this factor by specifically stating that a fiduciary must discharge his responsibility to the participants and beneficiaries "by diversifying

93 See Address by Ian Lanoff, Administrator, Dep't of Labor Pension and Welfare Benefit Programs, Eighth Annual Pension Conference held by Institutional Investor (Jan. 10-11, 1980) (reported in [1980] Pens. ReP. (BNA), Jan. 14, 1980 (No. 273), at A-13 to A-14).

9444 Fed. Reg. 37,224 (1979). 
the investments of the plan so as to minimize the risk of large losses, unless under the circumstances it is clearly prudent not to do so." 95 Although there is no fixed limit on the degree of investment concentration, the conference report lists a number of relevant facts and circumstances: "(1) the purposes of the plan; (2) the amount of the plan assets; (3) financial and industrial conditions; (4) the type of investment, whether mortgages, bonds or shares of stock or otherwise; (5) distribution as to geographical location; (6) distribution as to industries; (7) the dates of maturity." 96

The statute's policy of diversification might well make it easier to invest a small percentage of the plan's assets in socially desirable investments whose characteristics differ from the other investments in the portfolio, but the diversification rule places an important limit on the breadth of any specific program of social investing. The conference report states unequivocally that a fiduciary could not, for example, decide to devote all or even a substantial part of the plan assets to local investments: "the fiduciary should not invest the whole or an unduly large proportion of the trust property in ... various types of securities dependent upon ... conditions in one locality, since the effect is to increase the risk of large losses." 97 A similar limitation applies to mortgage investments. ${ }^{98}$ Thus, even a socially desirable investment that is financially sound in terms of risk, return, and liquidity may not be permissible under ERISA because of the diversification rule of the statute.

In summary, the federal prudence and diversification rules neither absolutely preclude nor specifically authorize the selection of investments that may be partially motivated by nonfinancial considerations. ERISA requires the fiduciary to undertake an analysis of the suitability of the individual investment. The analysis should compare the risks and return associated with the investment to the needs of the plan and the characteristics of the remainder of the plan's portfolio; one also should consider the availability of alternative investments that could serve the plan's needs at least as well.

This analysis may well produce a range of investment alternatives that are truly comparable in terms of serving the plan's articu-

9529 U.S.C. $\$ 1104(\mathrm{a})(1)(\mathrm{C})(1976)$.

96 CONFERENCE REPORT, supra note 56, at 304, reprinted in [1974] U.S. CoDE Cong. \& Ao. News 5038, 5084-85, also reprinted in 3 ERISA LEg. Hist., supra note 43 , at 4277,4571 .

97 Id.

98 "[The fiduciary] should not invest a disproportionate amount . . . in mortgages in a particular district or on a particular class of property so that a decline in property values in that district or of that class might cause a large loss." Id. 
lated investment objectives, thereby giving the fiduciary some latitude in considering nonfinancial characteristics of the investment alternatives. But, even if the plan's investment objectives have not been compromised to produce collateral "social" results, the fiduciary must still consider the other standards that govern his conduct.

\section{Social Investing Under the "Solely in the Interest of the Participants and Beneficiaries" Rule}

An investment program satisfying the threshold financial requirements of the prudence rule contained in section 404 (a) (1) (B) also must be undertaken "solely in the interest of the participants and beneficiaries" as required by ERISA section 404 (a) (1) ${ }^{99}$ The "solely in the interest" test is an extension of the common-law principle imposing on a trustee an undivided duty of loyalty to the beneficiaries in the administration of a trust.100 As with the common-law duty of loyalty, this obligation applies to all responsibilities of the fiduciary and is of "fundamental" importance.101 It stands at the head of ERISA's section on fiduciary responsibility, and is complemented by the specific admonitions in section 404 and the detailed proscription of self-dealing contained in sections 406 and $407 . .^{102}$ Because of the importance of this principle to the scheme of the statute, and because this language directly addresses the problem of the purpose of plan investments, any proposed social investment must be scrutinized closely under this rule.

\section{The "Solely in the Interest" Requirement as a Proscription of Self-Dealing}

Although the guiding principle of ERISA section 404(a)(1) springs from the common law, its language appears to have been drawn from the Internal Revenue Code and the Taft-Hartley Act. ${ }^{103}$ The case law interpreting these statutes suggests that, despite the rigidity of terms such as "sole" and "exclusive," an in-

9929 U.S.C. $\$ 1104(\mathrm{a})(1)(1975)$. The preamble to the final prudence regulation explains that a reference to the "solely in the interest" language of $\$ 404(a)(1)$ was deleted from the final regulation "to avoid suggesting that satisfaction of the 'prudence' rule with respect to an investment or investment course of action necessarily implies satisfaction of that additional requirement." 44 Fed. Reg. 37,222 n.2 (1979). This delineation between the separate and distinct concepts of prudence and loyalty is embedded in the structure of the Act and the common law.

100 See notes 34-38 supra \& accompanying text.

101 See 2 Scotr on Trusts, supra note 34, at 1297.

102 See 29 U.S.C. $\$ \$ 1106,1107$ (1976).

103 See notes 39-53 supra \& accompanying text. 
vestment resulting in an incidental benefit to a third party does not necessarily violate the statute. ${ }^{104}$ The crucial question is whether the primary purpose of the investment is to benefit the participants or beneficiaries of the trust. ${ }^{105}$ Purpose is not to be evaluated, however, solely on the basis of declarations of subjective intent by the fiduciary; an inference may be drawn from the practical effects of the fiduciary's actions. ${ }^{106}$

At a minimum, the "solely in the interest" test of section 404(a)(1) would proscribe any form of social investing with the primary purpose of benefiting any party responsible for the management or administration of the trust. Thus, an employer whose social-investing plan consists of a program of local investments designed to strengthen the financial viability of his customers or commercial lenders is not acting "solely in the interest of the participants and beneficiaries." Similarly, it has been held to be a violation of ERISA's duty of Ioyalty for a plan to purchase employer securities or employer debt obligations without considering the paramount interests of the participants and beneficiaries. ${ }^{107} \mathrm{Al}$ though such programs might provide incidental benefits to the participants both as employees and as local residents, the employer may find it difficult to demonstrate that its interests were not given paramount consideration. ${ }^{108}$

Similarly, the "solely in the interest" test would proscribe any social investment whose primary purpose is to benefit the employees' union, even though the employees may benefit indirectly as well. This application of the principle of loyalty is illustrated in Blankenship v. Boyle, ${ }^{109}$ a case decided prior to the enactment of ERISA under the common law and section 302(c)(5) of the TaftHartley Act.110 The district court held that the United Mine Workers Welfare and Retirement Fund, jointly administered by the

104 See notes 44 \& 45 supra \& accompanying text.

105 Rev. Rul. 69-494, 1969-2 C.B. 88.

108 See Feroleto Steel Co. v. Commissioner, 69 T.C. 97, 108 (1977).

107 Freund v. Marshall \& Ilsley Bank, [1979] PeNs. ReP. (BNA), Oct. 22, 1979 (No. 262), at D-1 (W.D. Wis. Sept. 24, 1979); Eaves v. Penn, 426 F. Supp. 830 (W.D. Okla. 1976), aff'd in relevant part and remanded on other grounds, 587 F.2d 453 (10th Cir. 1978).

108 Cf. Exemption from Prohibitions Respecting a Transaction Involving Stryco Manufacturing Co. Pension Trust, 41 Fed. Reg. 20,455, 48,200 (1976) (extension of loan for rebuilding of employer's plant destroyed by fire requires an exemption from prohibited transaction rules).

109329 F. Supp. 1089 (D.D.C.), stay denied per curiam, 444 F.2d 1280 (D.C. Cir. 1971), aff'd mem., 511 F.2d 447 (D.C. Cir. 1975).

11029 U.S.C. $\$ 186(c)(5)(1976)$. See notes 46-48 supra \& accompanying text. 
UMW and the coal industry, had imprudently maintained excessive funds in noninterest-bearing accounts in a bank owned by the union. The plaintiffs also challenged investments by the trust fund in certain public utility companies on the theory that these investments had been acquired in order to force the utilities to purchase coal produced by unionized companies. The evidence showed that the Fund's acquisitions of utility stock had been coordinated with those of the union and that the union had exercised the Fund's proxies. ${ }^{111}$ The court concluded that "[t] he intimate relationship between the union's financial and organizing activities and the utility investment activities of the trustees demonstrates that the Fund was acting primarily for the collateral benefit of the union and the signatory operators in making the most of its utility stock acquisitions." 112 The court therefore found a "clear case of selfdealing" on the part of the union and management representatives and also held the union liable for conspiring to benefit from the breach of trust. ${ }^{113}$

These conclusions of law in Blankenship $v$. Boyle are remarkable for two reasons. First, although the investments had declined in value, the court's holding rested on a breach of the duty of loyalty and not on a violation of the prudent-man rule. Second, in an unrelated portion of the opinion, the court recognized that, "[i]n the longer view of matters, the union's strength protects the interests of the beneficiaries, past and prospective." 114 Indeed, the court specifically noted that "while the beneficiaries have suffered as a result of the Fund's loss of investment income, they have benefited to some extent from the union's activities over the past twenty years." 115 Thus, the court found a breach of the duty of loyalty to the Funds' beneficiaries despite an express recognition that, in an indirect sense, workers would benefit from investment practices that strengthened the union. ${ }^{116}$

The ERISA obligation on fiduciaries to act in the interests of the participants and beneficiaries is at least as stringent as the common-law obligation enforced in Blankenship $v$. Boyle. A pri-

111329 F. Supp. at 1105-06.

112 Id. 1106.

$113 \mathrm{Id}$.

114 Id. 1112.

$115 I d$.

116 Recently, Blankenship has been characterized as a case "in which the trustees pursued policies which may incidentally have aided the beneficiaries of the fund but which were intended, primarily, to enhance the position of the Union and the welfare of its members." "Withers v. Teachers Retirement Sys. of N.Y., 447 F. Supp. 1248, 1256 (S.D.N.Y. 1978), aff'd, 595 F.2d 1210 (2d Cir. 1979). 
mary legislative justification for ERISA's enactment was the failure of common-law remedies to ensure the integrity of employee pension plans. ${ }^{117}$ The legislative history evinces deep congressional concern not only with conflicts of interest on the part of employerssuch as investment in employer stock-but also with union selfdealing. ${ }^{118}$ The courts have followed suit and found a breach of the duty to act solely in the interests of the participants and beneficiaries when, for example, plan assets are used to pay salaries of plan employees who are engaged principally in conducting the business of the union.119 Thus, at a minimum, the "solely in the interest" test of ERISA section 404 (a) (1) prohibits any socialinvesting program founded simply on the notion that a stronger union or stronger employer would be of indirect benefit to the participants and beneficiaries.

It may be a thin line separating investments "solely in the interest" of participants from those intended to benefit the company or the union. For example, William Sidell, Vice President of the AFL-CIO Building Trades Department, has argued that a policy of investment in unionized projects will "not only provide earnings to fund retirement benefits, but will also help assure that the plan is still ongoing by the time the participant is ready to retire." 120 Others may argue that investments strengthening the employer are necessary if the employer's financial weakness impairs its ability to contribute to the plans, thereby imperiling employee benefits.

An interesting analogy is provided by Withers $v$. Teachers Retirement System of New York, ${ }^{121}$ in which courts applying common-law fiduciary standards upheld the decision of the New York City municipal unions to commit more than $\$ 2.5$ billion of their pension funds to the speculative bonds of financially ailing New York City. The district court concluded that "neither the protection of the jobs of the City's teachers nor the general public

117 See notes 60-62 stura \& accompanying text.

118 See 120 Cong. REc. 29956-57 (1974) (remarks of Sen. Ribicoff), reprinted in 3 ERISA LEG. HIST., supta note 43, at 4811-12; 120 Cong. REc. 29951 (1974) (remarks of Sen. Bentsen), reprinted in 3 ERISA LEG. Hist., supra note 43, at 4795-96; 120 CoNG. Rec. 29932 (1974) (remarks of Sen. Williams), reprinted in 3 ERISA LEg. Hist., supra note 43, at 4743; 120 Cong. Rec. 29192-93 (1974) (remarks of Rep. Perkins), reprinted in 3 ERISA LEG. Hrst., supra note 43, at 4657; 120 CoNG. Rec. 4281 (1974) (remarks of Rep. Gaydos), reprinted in 2 ERISA LEG. HIST., supra note 43 , at 3377 .

119 E.g., Marshall v. Snyder, 430 F. Supp. 1224 (E.D.N.Y. 1977), aff'd, 572 F.2d 894 (2d Cir. 1978).

120 Testimony Before President's Commission on Pensfon Policy (Dec. 11, 1979) (prepared statement on file with the University of Pennsylvania Law Review). 121447 F. Supp. 1248 (S.D.N.Y. 1978), affd, 595 F.2d 1210 (2d Cir. 1979). 
welfare were factors which motivated the trustees in their investment decision." 122 Rather, the trustees had sought to maintain the City's solvency because the City was the principal contributor to the funds and the ultimate guarantor of the employees' pensions. ${ }^{123}$ It should be noted, however, that the trustees responsible for the New York City rescue made their commitment conditional on both the passage of state legislation authorizing them to consider the need to maintain the City as a contributor to the funds and the receipt of federal assurances that such investments would not jeopardize the tax-exempt status of the funds under the exclusive-benefit rule of section 401 of the Internal Revenue Code. ${ }^{124}$ Furthermore, the fact pattern of Withers, involving the threatened bankruptcy of a key municipality, may be considered to be sui generis. Thus, Withers arguably states the exception rather than the rule with respect to plan investments intended to support a sponsoring employer. ${ }^{125}$

\section{The "Solely in the Interest" Requirement in the Absence of Self-Dealing}

Of course, not all forms of social investing need be tainted by fiduciary of self-dealing. ${ }^{26}$ A trustee's reasons for a particular social investment may derive from genuine concern for the welfare of plan participants and beneficiaries. For example, a policy of investment in local companies might be predicated on the thought that a stronger local economy will provide economic benefits to plan participants and their families. Also, a refusal to invest in

122 Id. 1256.

123 The court distinguished Blankenship v. Boyle, claiming that any benefit the Blankenship plan participants may have derived from the trust policy of investing in utilities to force them to buy union-mined coal was "incidental" to gains inuring to the union. See 329 F. Supp. at 1256; note 116 supra. This distinction, however, appears tenuous in light of the fact that the level of contributions to the UMW pension fund was a direct function of the tonnage of union coal mined.

124 See 447 F. Supp. at 1258.

125 Of course, such investments must also pass muster under the stringent "prohibited transaction" rules of ERISA, \$406, 29 U.S.C. \$1106 (1976). See notes 181-206 infra \& accompanying text.

120 It remains to be seen how the courts will approach future "ideological selfdealing" designed by a trustee to fulfill his own political or moral objectives. For example, it might be argued that a fiduciary who refuses to invest in companies doing business in South Africa because of his abhorrence of that country's racial policies is acting in his own interest and not that of the plan participants, even though the trustee derives no economic benefit from the investment plan. To avoid liability under the "solely in the interest standard," it would seem that the trustee would have to present, at the very least, some coherent showing that such an investment policy was undertaken with some notion of the interests of the plan participants in mind rather than as a mere expression of his own ideology. 
companies that persistently violate federal health and safety standards might rest on the premise that such a policy would pressure these companies into compliance, thereby indirectly shaping the prevailing standards for occupational safety in the industry in which the plan participants are employed. ${ }^{127}$

Cases in which the investment is prudent, in which there is no indication of self-interested conduct on the part of the fiduciary, and in which the employees are arguably receiving some benefit from the proposed investment policy pose the most difficult issues under ERISA section 404 (a) (1). The central issue then becomes whether an investment policy that confers benefits on plan participants as part of a much larger group-such as local residents or workers generally-satisfies.

Given the "solely in the interest" standard, this issue is best addressed by examining congressional attitudes towards social investing and particularly social investing that benefits plan participants as part of a larger group. ${ }^{128}$ The declaration of policy advanced in section 2 of ERISA ${ }^{129}$ makes no reference to the objective of providing nonfinancial benefits to the employees through a socially responsible investment policy, nor does it refer to any larger group of statutory beneficiaries. Indeed, the focus of this declaration and

127 In either case, the trustee's position might be fortified, if the employees or representatives formally endorsed the particular policy of social investment as consistent with the employees' interests.

128 See 119 CoNG. REc. 12076 (1973) (statement of Sen. Javits), reprinted in 1 ERISA LEG. Hust., supra note 43 , at 276.

129 ERISA, $\$ 2,29$ U.S.C. $\$ 1001$ (1976), provides in relevant part:

(a) The Congress finds that the growth in size, scope, and numbers of employee benefit plans in recent years has been rapid and substantial; ... that owing to the lack of employee information and adequate safeguards concerning their operation, it is desirable in the interests of employees and their beneficiaries, and to provide for the general welfare and the free flow of commerce, that disclosure be made and safeguards be provided with respect to the establishment, operation, and administration of such plans; . . . that owing to the inadequacy of current minimum standards, the soundness and stability of plans with respect to adequate funds to pay promised benefits may be endangered; that owing to the termination of plans before requisite funds have been accumulated, employees and their beneficiaries have been deprived of anticipated benefits; and that it is therefore desirable in the interests of employees and their beneficiaries, for the protection of the revenue of the United States, and to provide for the free flow of commerce, that minimum standards be provided assuring the equitable character of such plans and their financial soundness.

(b) It is hereby declared to be the policy of this Act to protect interstate commerce and the interests of participants in employee benefit plans and their beneficiaries, by requiring the disclosure and reporting to participants and beneficiaries of financial and other information with respect thereto, by establishing standards of conduct, responsibility, and obligation for fiduciaries of employee benefit plans, and by providing for appropriate remedies, sanctions, and ready access to the Federal courts. 
the accompanying findings is on the need for fiduciary standards that will ensure the financial "soundness" and "stability" of the plans. ${ }^{130}$

This emphasis is readily understandable in light of the factual record on which Congress acted. The hearings exposed numerous examples of self-dealing, mismanagement, and inadequate funding of plan obligations. ${ }^{131}$ The committee reports stress the need for strict fiduciary standards that would ensure that employees receive the benefits to which they are entitled. ${ }^{132}$ Thus, the key congressional concern was to find means to assure greater financial stability of employee benefit plans, ${ }^{133}$ not to encourage more creative uses of plan assets.

Indeed, although several proposals designed to encourage social investing were placed before Congress, none were enacted into law. For example, Walter Reuther of the UAW urged that Congress "provide within the framework of ... [the federal] standards enough latitude so that the trustees could invest, with proper safeguards, some of those trust funds in . . . high social priority projects." 134 His remarks, however, did not spark much enthusiasm from key congressmen. ${ }^{135}$

Later in the same hearings, Representative Pucinski asked Secretary of Labor George Shultz whether language should be written into the bill protecting investment managers who decided to invest in low-income housing for senior citizen members. ${ }^{136}$ Such investments could be constructed to benefit plan retirees. Shultz's answer was a cautious one, submitted in written form. Despite an awareness of the need to finance low-cost housing, he stated that "care must be taken to ensure that an effort to this end does not run counter to the purposes of employee benefit plans, which are

$130 I d$.

131 See notes 60-62 supra \& accompanying text.

132 See, e.g., 1973 H.R. REP., supra note 61, at 12, reprinted in [1974] U.S. Code Cong. \& AD. News 4639, 4650, also reprinted in 2 ERISA LEG. Hrst, supra note 43 , at 2348,$2359 ; 1973$ S. RkP., supra note 61 , at 2, reprinted in [1974] U.S. CoDe Cong. \& AD. News 4838, 4839, also reprinted in 1 ERISA Leg. Hist., supra note 43 , at 587,588 .

133 See 120 Cong. REc. 29928-31 (1974) (remarks of Sen. Williams) reprinted in 3 ERISA LEG. Hist., supra note 43 , at 4734 .

134 Private Welfare Hearings, supra note 16, at 194 (testimony of Walter Reuther).

135 See, e.g., $i d .195$ (remarks of Congressman Dent) ("I might observe that the committee has been giving serious consideration that the prudent investors rule be the guideline for investments in the private sector").

136 Id. 528 (question of Rep. Pucinski). See notes 146 \& 147 infra \& accompanying text. 
also socially desirable." ${ }^{137}$ The Administration did not wish to "single out employee pension funds from other investment sources to bear a larger burden of riskier investments and low yields such as would be required by section 511 of [the bill]." ${ }^{138}$ The Secretary also pointed out that the Administration bill already contained language which appeared to permit the parties establishing a plan to incorporate directions instructing a fiduciary to make certain investments without regard to the prudent-man rule. ${ }^{139}$ The language upon which the Secretary relied did not appear, however, in the enacted version of the bill, a further indication that Congress's intent may have been to narrow, rather than widen, the scope of the fiduciary's discretion.

A third proposal placed before Congress was a draft bill championed by Ralph Nader and Karen Ferguson of the Public Interest Research Group. This proposal envisioned the establishment of private, competitive retirement benefit funds that could place up to ten percent of their assets in social investments. The propriety of these investments would be judged by the extent to which they reduced expenses typically incurred during retirement. ${ }^{140}$ This proposal also drew unenthusiastic response from the committee, ${ }^{141}$ and once again, Congress refused to adopt any specific provision authorizing socially dictated or even socially sensitive investment policies, even though plan participants would benefit as part of a larger group.

In light of these congressional responses to specific proposals for social investing, it appears inappropriate to stretch the "solely

${ }^{137}$ Id. 529 (statement of George Shultz).

$138 \mathrm{Id}$. The bill to which the Secretary was referring, H.R. 17495, 91st Cong., 2d Sess., 116 CoNG. REc. 21601-04 (1970), required that private pension plans and foundations with assets of more than four million dollars invest up to $2.5 \%$ of their net assets in the securities of a National Development Bank that would lend funds for certain socially desirable purposes. See id., \$511; 116 Conc. Rec. 21584 (1970). The House Committee recommended deletion of this section of the bill and the House supported that decision. Id. 21587-90. The bill was ultimately enacted into law as the Emergency Home Finance Act of 1970, Pub. L. No. 91351,84 Stat. 450 (codified in scattered sections of 12 U.S.C.).

139 Private Welfare Hearings, supra note 16, at 529 (statement of George Shultz). Section 14 of the Administration bill, H.R. 16462, 91st Cong., 2d Sess. (1970), Private Welfare Hearings, supra note 16, at 1-13, contained general fiduciary standards and probibited-transaction rules, but provided in $\$ 14(c)(7)$ that nothing in that section would be construed to prohibit any fiduciary from "following the direction in the trust instrument or other document governing the fund insofar as consistent with the [prohibited-transaction rules of that section]." Id. 10.

140 Pension Plan Hearings, supra note 19, at 260 (statement of Ralph Nader and Karen Ferguson).

141 " $U p$ to now we know of no standard that controls investment decisions better than the prudent man rule. If we want to go beyond that, we could write specific limitations into the bill." Id. 293 (statement of Rep. Dent). 
in the interest" language of section 404(a). As the Act's declaration of policy makes clear, Congress enacted ERISA with the relatively narrow objective of assuring adequate financial security for retired workers. Even an investment policy that is intended to benefit plan participants as one small segment of the community of American citizens or workers may not be safe from attack. In such situations, the investment policy apparently is susceptible to challenge under ERISA on the ground that it is not "solely in the interest" of plan participants but rather is intended to vindicate the interests of a much larger group of beneficiaries.

Nevertheless, an argument can be made that when a fiduciary has narrowed his list of potential investments to economically comparable alternatives, the statute should not proscribe his selection of the alternative that in the long run may produce indirect benefits to the participants as members of some larger group. Assuming total financial comparability under the prudence standard between two investments and assuming further that the fiduciary acts without any trace of self-interest or self-vindication, it is difficult to see any harm in a socially sensitive investment policy that may produce some extra benefits for the participants. Although the prospect of such benefits may be speculative, and the magnitude of such benefits for the individual participant may not be impressive, the fiduciary may aid the interests of his beneficiaries more by opting for such an alternative than by randomly or arbitrarily choosing some other alternative that offers no potential by-product advantages at all. ${ }^{142}$

The problem with this analysis is that its assumptions may be unrealistic. Even though several investments may be economically comparable in terms of consistency with the plan's investment objectives, they may offer slight differences in probable risk, return, and diversification value. Thus, the selection of one alternative over another might involve some small sacrifice in financial value. Once noneconomic considerations are permitted entry into the analysis, there is a real danger that the fiduciary will be tempted to choose one investment on the basis of its perceived general utility to the community rather than to refine further the comparison of financial characteristics to determine whether there is actual equivalence between the investments. A further difficulty with the premises of

142 In recent testimony before the Subcommittee on Antitrust, Monopoly, and Business Rights of the Senate Committee on the Judiciary, Ian Lanoff, the Administrator of Pension and Welfare Benefit Programs of the Department of Labor, took the position that where two investments were equally desirable from an economic standpoint, social factors could then be considered in determining which investment to select. See STAFF REPORT, supra note 3, at 13. 
this argument is that the fiduciary may not be able to demonstrate that the socially sensitive policy followed was intended to benefit the interests of the beneficiaries, rather than to vindicate his own interests or views. ${ }^{143}$

Considering these difficulties, it is probably wiser for a plan fiduciary to act at all times with the interests of the plan participants, as participants, directly in mind. Senator Williams, the Senate floor manager of ERISA, recently emphasized this statutory focus on the retirement interests of participants:

[S]ituations may arise where the interests of active employees may be at odds with the retirement income security interests of those same employees or present retirees. In such cases, a pension plan fiduciary with investment responsibility must choose the course which is consistent with the primary duty of loyalty to the retirement income needs of plan participants. ${ }^{144}$

Construing the statute to place primary emphasis on the retirement interests of participants does not preclude all forms of social investing. Arguably, the Act's objective of assuring financial security for retired workers may be served by investments that not only help pay plan benefits, but also tend to reduce the expenses of plan participants during their retirement years. For example, an employee pension fund could supply capital to build low-cost housing for the elderly in a community where its beneficiaries reside. Investment in housing to be used in substantial part by the plan participants and their beneficiaries would appear to satisfy the "solely in the interest" standard and would be permissible if it met the prudence test. ${ }^{145}$ As the Senate Committee Report noted, the "most important purpose" of ERISA was "to assure American workers that they may look forward with anticipation to a retirement with financial security and dignity, and without fear that this period of life will be lacking in the necessities to sustain them as human beings within our society." ${ }^{148}$ Because an investment in housing for the elderly is consistent with that purpose, a court would be more

143 See notes 107-25 supra \& accompanying text. Union officials may have difficulty proving, for example, that a policy of investing only in unionized companies is intended to benefit the participants as workers rather than the union itself.

144125 Cong. Rec. S560 (daily ed. Jan. 24, 1979) (remarks of Sen. Williams). 145 See notes 136-39 supra \& accompanying text.

1461973 S. REP., supra note 61, at 13, reprinted in [1974] U.S. CoDE CoNG. \& AD. NEws 4838, 4849, also reprinted in 1 ERISA LEG. HIST, supra note 43, at $587,599$. 
likely to uphold a close, judgmental decision to invest in such housing challenged under the loyalty standard. ${ }^{147}$

Of course, this rationale, too, could be stretched to unreasonable limits. Will not a stronger local economy, or a free society, also benefit the plan participants in their retirement years? Perhaps, but with such a tenuous link, it is difficult to say that the primary purpose of such an investment is to benefit the plan participants, rather than to achieve some other purpose for some other group of beneficiaries. Moreover, it is questionable whether such psychological benefits are among the "necessities" that Congress intended to assure for retired workers. Indeed, the language of section $404(a)(1)(A)$ of the Act raises the issue whether a fiduciary can seek to maximize any benefits other than the purely financial ones to be paid from the plan's assets, a question discussed below.

\section{Social Investing Under the "Exclusive Purpose" Rule}

ERISA section 404 (a) (I) (A) requires that the fiduciary discharge his duties "for the exclusive purpose of: (i) providing benefits to participants and their beneficiaries; and (ii) defraying reasonable expenses of administering the plan." I48 Under standard principles of statutory construction, this exclusive-purpose requirement cannot be read simply as a reiteration of the duty of loyalty owed to the participants and beneficiaries under section 404(a)(1).149 Thus, courts will seek an interpretation which imposes some further limitation on a fiduciary's conduct.

What this additional limitation will be, however, is far from clear. One might argue, for example, that section 404 (a)(1) (A) restricts the permissible objectives of an investment program to maximizing the size and security of the fund from which cash benefits are to be paid. The language of the provision lends a certain plausibility to this argument. The command of section 401 (a) of the Internal Revenue Code-that the employer maintain the plan "for the exclusive benefit of his employees or their beneficiaries"-has been modified. The ERISA phrasing emphasizes that the fiduciary's exclusive purpose must be to provide benefits.150

147 Alternatively, a court presented with a difficult issue concerning a fiduciary's motives under the loyalty standard may avoid the problem by focusing greater scrutiny on the prudence test to determine whether the investment was actually "comparable" to other alternatives.

14829 U.S.C. $\$ 1104(\mathrm{a})(\mathrm{I})(\mathrm{A})(1976)$.

149 See $2 A$ J. Sutmerland, Statutes and Statutory Construction $\$ 46.06$ (4th ed. 1973).

150 See also ERISA Report, supra note 77, at 234 (pointing out that the conference report implies that compliance with Internal Revenue Code is not sufficient under the ERISA "exclusive purpose" rule). 
Although the term "benefits" is arguably broad enough to encompass all of the rewards-moral and financial, direct and indirectthat a participant might reap from an investment program, the term is used more narrowly throughout the Act to refer to those cash benefits that a participant or his family would receive in accordance with the specifications of the plan. ${ }^{151}$ Moreover, the word "benefits" in section $404(\mathrm{a})(\mathrm{I})(\mathrm{A})(\mathrm{i})$ occupies a position parallel to the term "expenses" in section $404(\mathrm{a})(1)(\mathrm{A})$ (ii), so that it appears to refer only to cash benefits under the plan rather than the potential indirect benefits of an investment program. Thus, if the "exclusive purpose" rule is viewed as a restriction on the investment objectives of a fiduciary, it could have a restrictive impact beyond that of the "solely in the interest" requirement, prohibiting socially sensitive as well as socially dictated investment practices.

Indeed, the "exclusive purpose" rule of section $404(\mathrm{a})(1)(\mathrm{A})$ reiterates and enforces the identical direction of ERISA section $403(\mathrm{c})(1) .{ }^{152}$ In the original version of the legislation, both of these "exclusive purpose" phrases appeared in the same section of the bill. The section entitled "Fiduciary Responsibility" began with the broad declaration, "[e]very employee benefit plan shall be deemed to be a trust," and then identified the "exclusive purposes" for which the trust assets were to be "held." ${ }^{153}$ Thus, this language was conceived as a general limitation on the purposes of an ERISA employee benefit plan and could be viewed as a restriction on the permissible investment objectives of such a plan.

There is some doubt, however, that the exclusive-purpose rule was intended to restrict investment activity. Rather, it is plausible to conclude that the provision was intended to govern only the expenditure of plan funds by prohibiting all disbursements other than the payment of benefits to the plan participants and their beneficiaries and the payment of reasonable administrative expenses. This construction is consistent with early Labor Department enforcement actions under ERISA that successfully relied on this provision to attack disbursements for excessive administrative fees and unnecessary expenses (such as the lease of an aircraft for the plan) in addition to payments of benefits not contemplated by the

151 E.g., ERISA, $\$ \$ 2(\mathrm{a}), 3(22), 3(34), 3(35), 29$ U.S.C. $\$ \$ 1001(\mathrm{a})$, $1002(22), 1002(34), 1002(35)$ (1976).

152 "[T]he assets of a plan shall never inure to the benefit of any employer and shall be held for the exclusive purposes of providing benefits to participants in the plan and their beneficiaries and defraying reasonable expenses of administering the plan." 29 U.S.C. $\$ 1103(\mathrm{c})(1)$ (1976).

153 H.R. 2, $\oint 111(\mathrm{a})(1)$, 93d Cong., lst Sess. (1973), I ERISA Leg. Hist., supra note 43 , at 41 . 
plan or to persons not covered by the plan. ${ }^{154}$ Because of the strength of the other fiduciary provisions discussed above, and in light of the apparent purpose of this provision to curb improper expenditures, there is little compelling need for the courts to apply the exclusive-purpose rule to investment issues. ${ }^{155}$

If, because of section 404(a)(I)'s all-encompassing introductory language, the exclusive-purpose rule is nevertheless construed to apply to investment activities, perhaps the most reasonable construction would be the fairly restrictive interpretation of the "solely in the interest" requirement discussed above. ${ }^{156}$ In this view, the "exclusive purpose" language would suggest that ERISA trusts are to be established and maintained for the limited purpose of providing retirement benefits and not for other, socially desirable purposes which provide collateral or speculative "benefits" to plan participants or appeal to the philosophical leanings of the plan sponsor or other parties associated with the plan.

In summary, although the issue is not free from doubt, the "exclusive purpose" language of ERISA section 404(a)(1)(A) may be construed as an additional restriction on the scope of permissible investment practices. In any event, the courts may face a difficult task integrating this subsection with the prudence rule of ERISA section 404(a)(I)(B) and the "solely in the interest" language of ERISA section $404(a)(1)$, that independently set minimum financial requirements and circumscribe the allowable objectives of an ERISA investment program.

\section{E. Social Investing and the "In Accordance With Plan Documents" Rule}

Some commentators have suggested that a key factor with respect to the legality of social investing is the type of authorization set forth in the governing trust document. ${ }^{157}$ This would be true in the context of private trusts, ${ }^{158}$ and to a limited extent for ERISA trusts. Certainly, if the trust agreement expressly proscribes any

164 Marshall v. Snyder, 430 F. Supp. 1224 (E.D.N.Y. 1977), affd, 572 F.2d 894 (2d Cir. 1978); Marshall v. Knee, No. C-33-77-93 (S.D. Ohio Dec. 30, 1977) (consent order); Marshall v. Wilson, No. 3-76-373 (E.D. Tenn. June 6, 1977) (consent order).

105 It has also been argued that the conference report treats the "solely in the interest" and "exclusive purpose" requirements as equivalent. ERISA Report, supra note 77 , at $232 \&$ n.6.

156 See notes 99-147 supra \& accompanying text.

157 See Ravikoff, supra note 5 , at 534-35.

158 See note 38 supra \& accompanying text. 
form of social investment, that prohibition can limit the trustee's investment activity.

The terms of the statute, however, do not appear to countenance the converse proposition. Under ERISA section 404(a)(1)(D), the plan documents cannot authorize a policy of social investment that would otherwise be impermissible under the fiduciary standards of the Act. ${ }^{159}$ Indeed, ERISA requires a fiduciary to disregard the plan documents if compliance with the documents would be inconsistent with any of the provisions of the Act.180 The plan documents cannot, therefore, remove or relax the requirements that a fiduciary act prudently and solely in the interests of the participants and beneficiaries. ${ }^{161}$ Nor can the plan documents be drafted to override other provisions, such as a fiduciary's obligation to review the investment activity undertaken by predecessor fiduciaries to the plan. ${ }^{162}$

The legislative history of ERISA confirms this interpretation of the statute. In identical language, the Senate and House committee reports explained that one reason for establishing federal fiduciary standards is to negate the tendency of the common law to permit deviations from fiduciary standards when authorized by the trust instrument.163 The common law of trusts "developed in the context of testamentary and inter vivos trusts ... with an attendant emphasis on carrying out the instructions of the settlor." ${ }^{164} \mathrm{Be}$ cause of this context, if the trust document included language authorizing investments that would otherwise be imprudent or an exculpatory clause relieving the trustee from liability for a breach of trust, the common law of many states might permit such a devia-

150 ERISA $\$ 404(\mathrm{a})(\mathrm{I})(\mathrm{D})$ requires that a fiduciary discharge his duties "in accordance with the documents and instruments governing the plan insofar as such documents and instruments are consistent with the provisions of this subchapter." 29 U.S.C. $\$ 1104$ (a) (1)(D) (1976).

160 This point is underlined by ERISA $\$ 410(a)$ : "Except as provided in sections 405 (b) (1) and 405 (d), any provision in an agreement or instrument which purports to relieve a fiduciary from responsibility or liability for any responsibility, obligation, or duty shall be void as against public policy." 29 U.S.C. $\$ 1110$ (a) (1976).

161 Eaves v. Penn, 587 F.2d 453 (10th Cir. 1978) (Even though profit-sharing plan had been restructured as employee stock-ownership plan, investment in employer stock would be subject to "prudence" and "solely in the interest" tests.).

162 Marshall v. Craft, 463 F. Supp. 493, 497 (N.D. Ga. 1978).

163 See 1973 H.R. REP., supra note 61, at 12, reprinted in [1974] U.S. CoDE Cong. \& AD. News 4639, 4650, also reprinted in 2 ERISA LEG. Hrsx., supta note 43, at 2348,$2359 ; 1973 \mathrm{~S}$. REP., supra note 61 , at 29 , reprinted in [1974] U.S. CoDE Cong. \& AD. News 4838, 4865, also reprinted in 1 ERISA LeG. HIST., supra note 43 , at 587,615 .

164 See sources cited in note 163 supra. 
tion from sound fiduciary principles. ${ }^{165}$ Whatever its value in the context of personal trusts, Congress viewed this principle as inappropriate in the context of employee benefit plans covering hundreds, or even thousands, of employees. Thus, ERISA was designed to require a fiduciary to act "in accordance with the documents and instruments governing the fund unless they are inconsistent with the fiduciary principles in this section." 166

Although the plan documents themselves cannot expand the scope of investments permissible under ERISA, they may direct fiduciaries with investment discretion to give special attention to particular types of investments. If such investments may be harmonized with the statutory rules of prudence, diversification, and loyalty, the plan documents may direct the fiduciaries to select such investments over other comparable alternatives. The plan documents might also be useful in establishing priorities between different social objectives. It is essential, however, that these general guidelines be formulated "solely in the interest of the participants and beneficiaries." 167 Investment guidelines tainted by other concerns would themselves be violative of the statute, no matter how much flexibility they demonstrated.

The plan documents may also allocate responsibility for making investments, including social investments, among the fiduciaries or delegate them to others. ${ }^{168}$ If the allocation or delegation of the fiduciary's authority follows the procedure set forth in the plan document, ${ }^{169}$ the Act expressly limits the potential liability of the named fiduciary. ${ }^{170}$ Thus, appropriate language in the plan documents will permit the named fiduciaries to allocate to a trustee sufficient authority to manage a portion of the portfolio in accord-

165 In some states, however, such deviations were precluded by statute. See note 38 supra.

1661973 H.R. ReP., supra note 61, at 13, reprinted in [1974] U.S. CoDE Cong. \& AD. News 4639, 4651, also reprinted in 2 ERISA LEG. Hrst., supro note 43, at 2348,2360 ; $1973 \mathrm{~S}$. ReP., supra note 61 , at 30 , reprinted in [1974] U.S. CoDE Cong. \& AD. News 4838, 4866, also reprinted in 1 ERISA LEG. Hrst., supra note 43 , at 587,616 .

167 ERISA, $\$ 404(a), 29$ U.S.C. \$1104(a) (1976).

108 ERISA, $\$ 405(\mathrm{c}), 29$ U.S.C. $\$ 1105(\mathrm{c})$ (1976).

169 ERISA, $\$ \$ 402(\mathrm{~b})(2), 405(\mathrm{c})(1), 29$ U.S.C. $\$ \$ 1102(\mathrm{~b})(2), 1105(\mathrm{c})(1)$ (1976). SEE CoNfERENCE RePoRT, supra note 56, at 301 , reprinted in [1974] U.S. Code Cong. \& AD. NEws 5038, 5081, also reprinted in 3 ERISA LEG. Hist., supra note 43 , at 4277,4568 . See also 29 C.F.R. \$2509.75-8, FR-13, FR-14 (1979).

170 The named fiduciary remains liable only to the extent he has failed to meet the Act's fiduciary standards with respect to selection of the delegate, establishment of the procedure used to allocate or delegate authority, or termination of the delegation when circumstances require such action. ERISA, $\$ 405(\mathrm{c})(2), 29$ U.S.C. $\S 1105(c)(2)(1976)$. 
ance with a socially sensitive investment policy. In that event, the named fiduciaries will no longer be responsible for each investment decision of the trustee. Nevertheless, the named fiduciaries do remain liable for failure to select a responsible trustee, ${ }^{171}$ for failure to review periodically the trustee's performance to ensure that it is in accordance with the duties of prudence and loyalty, ${ }^{172}$ or for originating any instructions on social investing that are inconsistent with the fiduciary standards of ERISA. ${ }^{173}$

Similarly, the plan documents may authorize the trustee to delegate investment authority over a portion of the portfolio to another person. The structure of the Act suggests, however, that the trustee remains liable for all investment decisions on those assets unless the person to whom authority is delegated is an "investment manager," which is a defined term in ERISA. ${ }^{174}$ An investment manager must be either a bank, an investment adviser registered under the Investment Advisers Act of 1940,175 or an insurance company, and must acknowledge in writing its role as a fiduciary. ${ }^{176}$ Thus, although an informal advisory committee not meeting this definition could suggest various types of social investments or recommend how stock held by the plan should be voted, ${ }^{177}$ both the trustee and the committee remain liable under the Act for implementing any instructions of the committee.

Moreover, every fiduciary to the plan can be held liable for concealing, enabling, or failing to remedy a breach of duty on the part of a cofiduciary.178 Thus, a named fiduciary or trustee aware that a cofiduciary has exercised its investment authority to make imprudent social investments must take appropriate remedial action,

171 See ERISA, $\$ 405(c)(2)(A)(i), 29$ U.S.C. $\$ 1105(c)(2)(A)(i)(1976)$. 17229 C.F.R. $\$ 2509.75-8$, Question FR-17 (1979).

173 See ERISA, $\$ 405$ (c)(2)(A)(ii), (iii), 29 U.S.C. $\S 1105$ (c)(2)(A)(ii), (iii) (1976). Although the plan may authorize the named fiduciaries to give directions to the trustee, the trustee is subject only to "proper" directions that are "made in accordance with the terms of the plan and which are not contrary to this subchapter." ERISA, $\S 403(\mathrm{a})(1), 29$ U.S.C. $\$ 1103$ (a)(1) (1976). The trustee may be held liable for following instructions which on their face violate the fiduciary standards of the Act. Conference Report, supra note 56, at 298-300, reprinted in [1974] U.S. CODE CoNG. \& AD. News 5038, 5078-81, also reprinted in 3 ERISA LEG. HIST., supra note 43 , at $4277,4565-67$.

174 See ERISA, $\$ \$ 402(\mathrm{c})(3), 403(\mathrm{a}), 29$ U.S.C. $\$ \$ 1102(\mathrm{c})(3), 1103(\mathrm{a})$ (1976). See also 29 C.F.R. \$2509.75-8, Question FR-15 (1979).

$175 \$ \$ 201-221,15$ U.S.C. $\$ \$ 80 \mathrm{~b}-1$ to -21 (1976).

176 ERISA, § 3(38), 29 U.S.C. \$1002(38) (1976).

177 As noted earlier, the recent Chrysler-UAW settlement appears to contemplate this kind of advisory committee. See note 14 supra.

178 ERISA, §405(a), 29 U.S.C. \$1105(a) (1976). ConfERENCE REPORT, supra note 56, at 299-300, reprinted in [1974] U.S. Code CoNG. \& AD. News 5038, 5080, also reprinted in 3 ERISA LEG. Hist., supra note 43, at 4277, 4566-67. 
such as selling the investment ${ }^{179}$ or reporting the violation to the Department of Labor. ${ }^{180}$

In summary, the plan documents can provide a framework for distributing investment authority and a list of priority investments, but they cannot expand the universe of permissible social investments beyond that authorized by the other ERISA standards, nor can they relieve the named fiduciaries and trustees of their ultimate responsibility for the safety of the plan assets.

\section{F. Social Investing and ERISA's Prohibited-Transaction Rules}

In addition to general fiduciary standards, ERISA contains "prohibited transaction" rules which may restrict certain types of activity often discussed in the context of social investing. ERISA section 406 (a) ${ }^{181}$ prohibits several kinds of transactions between a plan and a "party in interest" with respect to the plan and ERISA section $406(\mathrm{~b})^{182}$ precludes self-dealing on the part of plan fiduciaries. ERISA's prohibited-transaction rules are absolute struc-

179 Morrissey v. Curran, 567 F.2d 546, $548-49$ (2d Cir. 1977); see Marshall v. Craft, 463 F. Supp. 493,497 (N.D. Ga. 1978).

18029 C.F.R. $\$ 2509.75-5$, Question FR-10 (1979).

181 Under $\$ 406$ (a) (1) of ERISA, the following transactions are prohibited:

A fiduciary with respect to a plan shall not cause the plan to engage in a transaction, if he knows or should know that such transaction constitutes a direct or indirect-

(A) sale or exchange, or leasing, of any property between the plan and a party in interest;

(B) lending of money or other extension of credit between the plan and a party in interest;

(C) furnishing of goods, services, or facilities between the plan and a party in interest;

(D) transfer to, or use by or for the benefit of, a party in interest, of any assets of the plan; or

(E) acquisition, on behalf of the plan, of any employer security or employer real properiy in violation of section 407 (a).

29 U.S.C. $\$ 1106(a)$ (1976).

Section 4975(c) of the Internal Revenue Code contains a list of prohibited transactions very similar to the one in ERISA $\$ 406$.

182 Section 406(b) of ERISA imposes several additional constraints on the behavior of plan fiduciaries. Under this subsection, a fiduciary may not:

(1) deal with the assets of the plan in his own interest or for his own account;

(2) in his individual or in any other capacity act in any transaction involving the plan on behalf of a party (or represent a party) whose interests are adverse to the interests of the plan or the interests of its participants or beneficiaries; or

(3) receive any consideration for his own personal account from any party dealing with such plan in connection with a transaction involving the assets of the plan.

29 U.S.C. $\$ 1106$ (b) (1976). 
tural prohibitions; thus, the "reasonableness," "fairness," or "prudence" of a transaction is irrelevant.183 Despite the critical importance of these restrictions, they have rarely been analyzed in the context of discussions on social investing.

In order to appreciate the scope of the section $406(\mathrm{a})(1)$ prohibitions, one must take into account the breadth of the statutory definition of the term "party in interest." ERISA section 3(14) defines a "party in interest" to include not only all fiduciaries, but also any entity providing services to the plan, any employer or employee organization whose employees are covered by the plan, any person owning more than fifty percent of the employer, and any relative of the persons described above. ${ }^{184}$ The ERISA definition of "party in interest" extends even further to encompass affiliated persons such as employees, officers, directors, or ten percent shareholders of the previously described parties, and any enterprise in which those parties own an interest of fifty percent or more. ${ }^{185}$ Thus, the union and employer, and almost anyone and any company affiliated with them, will be "parties in interest" within the meaning of the Act, and therefore prohibited from dealing with the plan. ${ }^{186}$

183 Cutaiar v. Marshall, 590 F.2d 523 (3d Cir. 1979); M\&R Investment Co. v. Fitzsimmons, [1980] Pans. Rep. (BNA), Feb. 4, 1980 (No. 276), at D-9 (D. Nev. Jan. 14, I980). In Cutaiar, the court admitted that:

[T] his case involves no taint of scandal, no hint of self-dealing, no trace of bad faith. The violation was concededly a technical one, the result of a misunderstanding of the requirements of the newly enacted ERISA bolstered by the result of good faith submission of the dispute to impartial arbitration. Uncontradicted testimony before the district court established that the terms of the transaction were fair and reasonable with respect to both plans. Id. 528 .

Nevertheless, the court upheld the position of the Department of Labor that the transaction violated ERISA's prohibited transaction rules.

18429 U.S.C. $\$ 1002(14)$ (1976). Similarly, in M\&R Investment Co. v. Fitzsimmons, [1980] PENs. REP. (BNA), Feb. 4, 1980 (No. 276), at D-9 (D. Nev. Jan. 14, 1980), the court emphasized that neither lack of harm to the plan nor the good faith of the fiduciaries was relevant to a determination whether a prohibited transaction had occurred.

$185 \mathrm{Id}$. A pending amendment to ERISA, the ERISA Improvement Act of 1979 , proposes minor changes to the definition of "party in interest." See S. 209, 96th Cong., 1st Sess., 125 Cong. Rec. S561, S573 (daily ed. Jan. 24, 1979). The amendment would narrow the scope of the definition to permit dealings between the plan and 1) an intermittent provider of nonprofessional services, 2) an employer whose employees constitute less than five percent of all employees covered by the plan, or 3 ) an employee organization whose members constitute less than five percent of all employees covered by the plan. Id.

186 See, e.g., U.S. Dep't of Labor Adv. Op., No. 78-25, reprinted in [1978] Washington SERvice BUREaU, ERISA UpDATE [hereinafter cited as ERISA UpDATE]; U.S. Dep't of Labor Adv. Op., No. 77-14, reprinted in [1977] ERISA UPDATE, supra; U.S. Dep't of Labor Adv. Op., No. 76-91, reprinted in [1976] ERISA UPDATE, supra. 
The additional section 406(b) restrictions were introduced in the legislation to serve as absolute barriers to plan fiduciaries using their discretionary authority in situations involving real or struc. tural conflicts of interest. ${ }^{187}$ In this regard, the Act was patterned after the earlier Senate versions of the bill, which contained specific prohibitions against certain conduct, rather than after the earlier House versions, which required that a plan fiduciary merely meet the standard of an "arm's-length" transaction. ${ }^{188}$ The second proscription in particular-prohibiting a fiduciary from representing a party with interests adverse to those of the plan ${ }^{189}$-was designed to keep "a fiduciary from being put in a position where he has dual loyalties, and, therefore, he cannot act exclusively for the benefit of a plan's participants and beneficiaries." 190

The prohibitions that pose the greatest potential for difficulty in the area of social investing are those contained in ERISA sections 406(a)(I)(D) and (E) and 406(b)(1) and (2). For example, as in Blankenship v. Boyle, ${ }^{191}$ a union official who also served as a fiduciary to a plan covering union members might cause the plan to invest its assets in a manner intended to benefit the union. Because the union would be a "party in interest" under section $3(14)(\mathrm{D})$, such an investment would violate section $406(\mathrm{a})(1)(\mathrm{D})$, in that it would constitute the use of plan assets for the benefit of a "party in interest." No actual transfer of assets between the plan and the "party in interest" would be necessary for a prohibited transaction to occur. 192 Moreover, an indirect prohibited transaction would occur if a plan engaged in a transaction with a person who was not a "party in interest" with an understanding that that party would in turn engage in a transaction with a "party in interest." 193

18729 C.F.R. $\$ 2550.408 \mathrm{~b}-2$ (e)(1) (1979).

188 See Freund v. Marshall \& Ilsley Bank, [1979] Pens. Rep. (BNA), Oct. 22, 1979 (No. 262), at D-1, D-8 (W.D. Wis. Sept. 24, 1979); 120 Conc. Rec. 29932 (1974) (remarks of Sen. Williams), reprinted in 3 ERISA LEG. Hist., supra note 43 , at 4743 .

189 ERISA, $\$ 406$ (b)(2), 29 U.S.C. $\$ 1106$ (b)(2) (1976).

190 CoNmERENCE REPORT, supra note 56, at 309, reprinted in [1974] U.S. Code Cong. \& AD. NEws 5038, 5089, also reprinted in 3 ERISA LEG. Hist., supra note 43. at 4277,4576 .

191329 F. Supp. 1089 (D.D.C.), stay denied per curiam, 447 F.2d 1280 (D.C. Cir. 1971), affd mem., 511 F.2d 447 (D.C. Cir. 1975). See notes 109-19 supra \& accompanying text.

192 CONFERENCE RePont, supra note 56, at 308, reprinted in [1974] U.S. Cone Cong. \& AD. News 5038, 5089, also reprinted in 3 ERISA LEG. Hist., supra note 43, at 4277, 4575. See Marshall v. Snyder, 430 F. Supp. 1224 (E.D.N.Y. 1977), aff d, 572 F.2d 894 (2d Cir. 1978).

193 For examples of this phenomenon, see 29 C.F.R. $\$ 2509.75-2$ (1979). See also, e.g., U.S. Dep't of Labor Adv. Op., No. 75-103, reprinted in [1975] ERISA UpDate, supra note 186; U.S. Dep't of Labor Information Letter (WSB No. 78-17). 
This analysis also demonstrates the invalidity of an investment benefiting the employer who maintained the plan. ${ }^{194}$ Further, any direct investment by a defined benefit plan in employer securities or real property would be limited to ten percent of the fair market value of the plan's assets under ERISA sections $406(\mathrm{a})(1)(\mathrm{E})$ and $407(\mathrm{a}) .{ }^{195}$

In addition, an employer investing plan assets in a manner designed to promote the employer's business would most likely run afoul of the section $406(\mathrm{~b})(\mathrm{I})$ prohibition against dealing with plan assets in the fiduciary's own interest. ${ }^{196}$ Finally, any plan fiduciary representing another party's interest-for example, a union official serving as plan trustee and investing plan assets in order to foster the union's interests-might in some circumstances violate the section $406(\mathrm{~b})(2)$ prohibition against acting on behalf of a party with interests adverse to those of the plan. ${ }^{197}$

Although ERISA section 408 (b) ${ }^{198}$ provides several statutory exemptions from the Act's prohibited-transaction rules, these provisions would be inapplicable to the types of transactions that usu-

194 M \& R Investment Co. v. Fitzsimmons, [1980] Pens. Rep. (BNA), Feb. 4, 1980 (No. 276), at D-9 (D. Nev. Jan. 14, 1980). See also Labor Dep't Complaint, Marshall v. Schmoutey, Civ. Action No. CVLV 77-47 RDF (D. Nev., filed March 30, 1977), reproduced in [1977] PENs. ReP. (BNA), April 4, 1977 (No. 131), at R-1 to R-3 (alleging a violation of ERISA $\$ \$ 406(\mathrm{a})(1)(B)$ and $406(\mathrm{a})(1)(\mathrm{D})$ on the ground that the plan lent money to a corporation that was owned by an individual who in turn owned a corporation owming more than $10 \%$ of yet another corporation whose subsidiary employed persons employed by the plan). [1977] Pens. Rep. (BNA), April 4, 1977 (No. 13I), at R-1, R-3.

195 See notes 11,102 \& 181 supra \& accompanying text. This restriction does not apply to an eligible individual account plan such as an employee stockownership or profit-sharing plan, if the plan explicitly provides for the purchase of qualifying employer securities. See ERISA, $\$ 407$ (b)(1), 407(d)(3), 29 U.S.C. $\$ \S 1107(\mathrm{~b})(1), 1107(\mathrm{~d})(3)$ (1976). Even in such plans, however, the investment in employer stock must be prudent and solely in the interest of the participants. See Eaves v. Penn, 587 F.2d 453, 457-58 (10th Cir. 1978).

196 Because such transactions are prohibited, the parties have found it necessary to obtain exemptions from the Labor Department. See, e.g., Exemption from Prohibitions Respecting a Transaction Involving the Univar Retirement Plan, 41 Fed. Reg. 46,799 (1976); Exemption from Prohibitions Respecting a Transaction Involving Stryco Manufacturing Company Pension Trust, 41 Fed. Reg. 48,200 (1976); Exemption from Prohibitions Respecting a Transaction Involving the Given International Employees' Stock Bonus Plan, 41 Fed. Reg. 54,080 (1976).

197 Exemptions from the prohibited-transaction rules have been necessary in this context as well. See, e.g., Exemption from Prohibitions Respecting Certain Transactions Involving the Alaska Teamsters-Employer Pension Trust, 41 Fed. Reg. 16,642 (1976); Exemption from Prohibitions Respecting Transaction Involving International Brotherhood of Electrical Workers Local Union No. 606 Health and Welfare Fund, 41 Fed. Reg. 30,414 (1976); Exemption from Prohibitions Respecting a Transaction Involving the Iron Workers' Apprentice Fund, 42 Fed. Reg. 13,633 (1977).

19829 U.S.C. $\$ 1108$ (b) (1976). 
ally arise in the context of social investing. ${ }^{199}$ A fiduciary truly determined to pursue a course of social investing could also attempt to seek an administrative exemption according to the procedures detailed in section $408(a) .{ }^{200}$ This process, however, is expensive and time consuming; most prohibited-transaction exemption applications are handled on a case-by-case basis. ${ }^{201}$ And even if the fiduciary is granted an exemption from the prohibitions of section 406, the exemption cannot override general ERISA standards. The fiduciary would remain bound by the prudence and loyalty requirements of section $404 . .^{202}$

The limited utility of the exemption procedure as a means of furthering a policy of social investing is illustrated in one case in which such an exemption was granted to permit an otherwise prohibited socially sensitive investment. Multiple-employer plans covering employees in the building trades traditionally have invested a percentage of their assets in construction loans to contributing employers as a means of providing work opportunities for plan participants. Even though such loans may be intended to promote the interests of plan members, they are inconsistent with the strucural prohibition of ERISA section 406(a)(1)(B).

Thus, in order to preserve this practice, the Labor Department found it necessary to grant a limited class exemption covering such loans. $^{203}$ The exemption restricts the practice in a number of important respects, however. For example, the loan decision must be made by an independent bank, savings and loan association, or insurance company; the aggregate amount of such loans to a single employer must not exceed ten percent of the plan assets; and the aggregate amount of such loans to all participating employers must not exceed thirty-five percent of the plan assets. ${ }^{204}$ In addition,

190 Section 408(b) permits, for example, fair and reasonable loans to plan participants and beneficiaries and investment of plan assets as deposits in a fiduciary bank in certain situations. See ERISA, $\$ 408$ (b), 29 U.S.C. $\$ 1108$ (b) (1976).

20029 U.S.C. $\S 1108$ (a) (1976). See also 40 Fed. Reg. 18,471 (1975); Exec. Order No. 12,108, 44 Fed. Reg. 1065 (1979) (ordering the implementation of Reorganization Plan No. 4 of 1978, 43 Fed. Reg. 47,713 (1978)).

201 See, e.g., notes $196 \& 197$ supra (exemptions).

20229 U.S.C. $\$ 1104$ (1976). All the administrative exemptions granted thus far contain specific language stating that the plan fiduciaries must still adhere to the general standards of ERISA $\$ 404$.

203 Prohibited Transaction Exemption 76-1, Class Exemptions From Probibitions Respecting Certain Transactions in Which Multiemployer and Multiple Employer Plans Are Involved, 41 Fed. Reg. 12,740 (1976).

204 Id. $12,743$. 
the exemption does not authorize the use of plan assets for permanent mortgage loans for the benefit of contributing employees. ${ }^{205}$

In view of the impact of ERISA's prohibited-transaction rules on at least certain social-investing practices, major structural changes in the law may be required to permit many of the types of transactions often considered in the context of social investing. The currently existing exemption process would require the Department of Labor to decide directly which "socially desirable" investments are "in the interests of the plan and its participants and beneficiaries," and "protective of the rights of participants and beneficiaries of such plan." 206 It is doubtful, however, whether the Department, the Congress, or the public at large would favor such a broad and unstructured grant of authority to pass judgment on the merits of a given form of social investing. A legislative remedy may therefor be necessary.

\section{The Prospect of Litigation Involving Social Investing}

To date, there has been no litigation under ERISA challenging the social-investment practices of private employee benefit plans. It would not be surprising, however, if such litigation accompanied the spread of social-investment theory and practice. The jurisdictional provisions of the statute encourage suits by plan members and fiduciaries; in addition to the. Department of Labor, any participant, beneficiary, or fiduciary can sue the plan or its fiduciaries. ${ }^{207}$ The federal district courts have jurisdiction of such actions without regard to jurisdictional amount ${ }^{208}$ and are authorized to provide complete relief. ${ }^{209}$ Finally, as an incentive to such suits, the statute authorizes the court to award attorneys' fees to the prevailing party. 210

In addition to such statutory encouragement, the number of potential plaintiffs also suggests the likelihood of future litigation. As noted earlier, ${ }^{211}$ litigation seems much more likely in the case

205 Id. 12,742. Thus, a commitment from a plan to a participating employer to provide permanent mortgage loans to persons purchasing improved real property from the participating employer, would be prohibited by the Act.

206 ERISA, $\$ 408(a)(2),(3), 29$ U.S.C. $\$ 1108(a)(2),(3)$ (1976).

207 ERISA, $\$ 502$ (a), 29 U.S.C. $\$ 1132$ (a) (1976).

208 ERISA, $\$ 502(f), 29$ U.S.C. $\$ 1132(f)$ (1976). An action may be brought in the district where the plan is administered, where the breach took place, or where any defendant may be found. Once proper venue is established, the district court may assert personal jurisdiction over every defendant, including, of course, all plan fiduciaries. ERISA, $\$ 502(\mathrm{e})(2), 29$ U.S.C. $\$ 1132(\mathrm{e})(2)$ (1976). 209 ERISA, $\S \S 409(a), 502(a)(2),(3), 29$ U.S.C. $\$ \$ 1109(a), 1132(a)(2)$,

(3) (1976).

210 ERISA, $\$ 502(\mathrm{~g}), 29$ U.S.C. $\$ 1132(\mathrm{~g})$ (1976).

211 See text accompanying notes $80 \& 81$ supra. 
of a defined contribution plan. The participants in such a plan will immediately feel the sting of an unsuccessful social investment and, in light of the visibility of their individual accounts, are more likely to take an interest in the investment policy of the plan. Even in a defined benefit plan, however, a lawsuit might be prompted by the prospect that a loss of plan assets in a social investing project will preclude an increase in benefits at the next amendment to, or renegotiation of, the plan. In addition, there may be some employees who disagree on ideological grounds with the social-investment policy followed by the plan or who wish to challenge the concept of using plan assets for social purposes. ${ }^{212}$ Finally, there is always the possibility that a fiduciary opposed to risking the assets of the employer to achieve social goals might decide to challenge a program of social investment in court.

A lawsuit challenging a social-investment program may have serious consequences for the plan and its fiduciaries. Most fiduciaries are aware that they may be held personally liable in damages for an investment found by a court to be imprudent. They may not realize, however, that they may be held liable in damages for any violation of the other fiduciary standards of the statute..$^{213}$ Thus, if a loss ensues from a program of social investing which is not "solely in the interest of the participants and beneficiaries," the responsible fiduciaries might be required to restore the lost assets to the plan regardless of the prudence of the investment.214

A lawsuit for damages in the context of a defined benefit plan presents unique problems. If the plan experiences losses or fails to reap achievable gains as a result of a socially dictated investment policy, the plaintiff-participants could force the fiduciaries, including the representatives of the employer, to restore the lost funds or

212 See, e.g., Sacramento Unions Blast "Social" Concept, Pensrons \& InvestMENTS, Nov. 5, 1979, at 1 .

213 ERISA $\$ 409$ (a) states:

Any person who is a fiduciary with respect to a plan who breaches any of the responsibilities, obligations, or duties imposed upon fiduciaries by this subchapter shall be personally liable to make good to such plan any losses to the plan resulting from each such breach, and to restore to such plan any profits of such fiduciary which have been made through use of assets of the plan by the fiduciary, and shall be subject to such other equitable or remedial relief as the court may deem appropriate, including removal of such fiduciary.

29 U.S.C. $\$ 1109$ (1976).

214 Similarly, a trustee who violated his duty of loyalty under the common law would be held liable for all losses, regardless of the fairness or prudence of the investment. See Restatement (Second) of Trusts \$206 (1959); 2 Scotr on Trusts, supra note 34 , at $\S 170$. 
profits to the plan.215 Although the employer would in any case be required to compensate for any deficiency in the investment performance of the plan's portfolio as a result of his obligation under the funding standards of ERISA, that obligation can be amortized over a period of many years. ${ }^{216}$ A suit for restitution under ERISA, however, could force the employer to make an immediate lump-sum payment-a greater burden than the employer may have contemplated.

Although a judicial challenge to a profitable program of social investing is less likely, even in this situation a lawsuit may have undesirable consequences for the plan fiduciaries. ${ }^{217}$ First, a plaintiff who successfully shows that the program was inconsistent with the fiduciary standards of the statute would be entitled to an injunction terminating the program. ${ }^{218}$ Removal of the responsible fiduciaries would also be a possibility. ${ }^{219}$ The fiduciaries might be required to pay the attorneys' fees of the successful plaintiff. ${ }^{220}$ Thus, even in a situation in which a socially dictated investment is unlikely to produce a loss, there are sound practical reasons why fiduciaries may wish to avoid any deviation from the fiduciary standards of the statute.

In view of the possibility that a program of social investing will provoke litigation, any plan embarking on such a program should construct a solid analytical foundation. The fiduciaries must first examine the needs and objectives of the plan and may find

215 ERISA, $\$ 409$ (a), 29 U.S.C. $\$ 1109$ (a) (1976). See Eaves v. Penn, 587 F.2d 453, 463 (10th Cir. 1978); Freund v. Marshall \& Ilsley Bank [1979] PeNs. REP. (BNA), Oct. 22, 1979 (No. 262), at D-1, D-11 (W.D. Wis. Sept. 24, 1979).

216 See, e.g., ERISA, $\$ 302$ (b)(2)(B)(iv), 29 U.S.C. $\$ 1082$ (b)(2)(B)(iv) (1976) (authorizing the amortization of net experience losses over a period of 15 years for a single employer, and 20 years for a multi-employer plan).

217 Additionally, a violation of the prohibited-transaction rules of ERISA, $\S 406$, 29 U.S.C. $\$ 1106$ (1976), may lead to a penalty against the "party in interest" amounting to five percent of the amount involved in the transaction and up to $100 \%$ of that amount if the transaction has not been corrected within 90 days of notice from the Government. I.R.C. $\$ 4975$; ERISA, $\$ 502(i), 29$ U.S.C. $\$ 1132(i)$ (1976).

218 Pursuant to ERISA $\$ 502(a)(3)$, a participant, beneficiary or fiduciary may sue "(A) to enjoin any act or practice which violates any provision of this subchapter or the terms of the plan, or (B) to obtain other appropriate equitable relief (i) to redress such violation or (ii) to enforce any provision of this subchapter." 29 U.S.C. $\$ 1132(\mathrm{a})(3)(1976)$.

219 ERISA, $\$ 409$ (a), 29 U.S.C. $\$ 1109$ (a) (1976). See Eaves v. Penn, 426 F. Supp. 830, 838 (W.D. Okla. 1976), affd, 587 F.2d 453 (10th Cir. 1978).

220 ERISA, $\$ 502(\mathrm{~g}), 29$ U.S.C. $\$ 1132(\mathrm{~g})$ (1976). See Eaves v. Penn, 587 F.2d 453 (10th Cir.); Mahoney v. Union Leader Retirement Profitsharing Plan, [1979] PeNs. ReP. (BNA), July 16, 1979 (No. 248), at D-4 (D.N.H. July 9, 1979) (consent order providing for payment of more than $\$ 200,000$ in attorneys fees and expenses); Kulchin v. Spear Box Co., 451 F. Supp. 306 (S.D.N.Y. 1978) (awarding $\$ 9,041.25$ in attorneys' fees $\rangle$. 
it necessary to call on advisors with financial or investment expertise to develop a rational strategy to meet those needs. Legal advisors may be consulted on general legal standards, but lawyers should not be expected to shed much light on primarily factual questions such as the suitability of particular investments for the portfolio. In addition, it will usually be more helpful to have the lawyer review the strategy after it has been developed than to have the lawyer venture from his expertise to describe at the outset what should be done.

A linchpin in the defense of any investment is a proper rationale for the investment decision at the time it is made.221 The Labor Department's prudence regulation, in focusing on the reasonableness of the procedures and information used by fiduciaries in making investment decisions, suggests that the Department is developing a rule based on the fiduciary's conduct at the time of decision rather than a "hindsight" test based on economic results. ${ }^{222}$ Thus, prior to undertaking any socially sensitive investment, the plan should complete an analysis demonstrating the investment's contribution to the achievement of the plan's investment objectives. Moreover, the fiduciary should develop empirical support for his view that the investment will advance the retirement interests of the beneficiaries. In the event of challenge, a social investment supported by such a contemporaneous rationale is more likely to be characterized by a court as socially sensitive (and permissible) than socially dictated (and impermissible).

Some fiduciaries may prefer to avoid such documentation on the theory that it eases the challenger's proof that social investing has occurred. Apart from the duplicity of this approach, it seems naive to suggest that any effective social-investing policy can be hidden from discovery. On balance, a policy of social investing is better protected by a documentary foundation, which permits an effective defense, than by efforts at concealment, which are likely to provoke the curious to investigate.

This principle does not require a separate, extensive, contemporaneous analysis supporting every decision to include or exclude an investment. When adequate empirical data is available, it may be possible to develop more general guidelines that permit the fiduciary to include or exclude groups of investments. The point is simply that the evidence supporting such guidelines should be con-

221 See Stark v. United States Trust Co., 445 F. Supp. 670, 680-81 (S.D.N.Y. 1978); In re Morgan Guaranty Trust Co., 89 Misc. 2d 1088, 1090, N.Y.S.2d 781, 784 (Sur. Ct. 1977 ).

222 See 29 C.F.R. $\$ 2550.404 a-1$ (b)(1) (1979). 
sidered prior to implementing them and not developed or examined for the first time when the issue is raised in court.

Of course, not all social investments will lead to litigation. In the absence of any explicit regulatory guidance or definitive judicial decisions, it is difficult to state with precision whether a particular investment policy will be found to violate ERISA. Even an investment pressing the outer limits of ERISA's fiduciary standards may not be challenged because of the lack of a plaintiff with a sufficient financial interest to challenge the investment. In light of these practical considerations, the fiduciary must decide what degree of comfort he will demand from the law and empirical data supporting his investment decisions. Although the possibility of litigation should be considered, in many cases it should be viewed as simply another risk created by the investment policy.

\section{Summary and Concluston}

The legal framework established by ERISA is both comprehensive in its coverage of the activities of plan fiduciaries and complex in the restrictions it places on their management or disposition of plan assets. Thus, any summary of its application to social investing runs the risk of misleading oversimplification. Reduced to its essence, however, ERISA appears to require that every plan investment be subjected to a three-part analysis.

In the first part, the responsible fiduciary must determine whether the financial characteristics of the investment will satisfy the prudence and diversification requirements of the statute. The fiduciary must evaluate the safety, return, marketability, and diversification characteristics of the proposed investment in order to determine whether, in the context of the plan's entire portfolio, the investment will aid the plan in achieving its investment objectives. Those objectives in turn should have been formulated with due regard for the plan's design, funding, liquidity needs, and other individual characteristics. Thus, the financial needs of the plan will lead to the establishment of investment objectives designed to meet those needs. In turn, those objectives can be achieved by adopting investment strategies which use one or more groups of economically comparable investments. Although a fiduciary may be able to invoke a socially sensitive investment policy in order to select among these alternative investments, a socially dictated investment policy, in which financial comparability is sacrificed in order to achieve some social purpose, will not withstand scrutiny under this part of the statutory analysis. 
In the second part of the analysis, the fiduciary's actions in selecting particular strategies or investments must be reconciled with the purposes declared permissible by the statute. If there is any element of self-interest in the choice of investments, whether that interest is financial or ideological, then the statute may well prohibit such conduct. Even where the fiduciary acts without regard to his own interests, it is nevertheless essential that the investment program be designed primarily to further the interests of participants and beneficiaries. If the fiduciary faces a choice between investments with identical financial characteristics, it may be possible to choose an alternative that offers indirect benefits to plan participants as members of some larger community. But, in light of the difficulty in proving both a pure motive and financial equivalence, it may be more sensible to develop an investment policy designed to permit only those investments that aid the interests of the plan participants as participants. Under this criterion, then, even some socially sensitive investment policies could be rejected as inconsistent with the objectives of the statute.

Finally, each transaction must be consistent with the structural standards of ERISA. If the investment will benefit a "party in interest," such as the employer or union, the plan may find it necessary to obtain an exemption from the "prohibited transaction" rules of the statute. In all events, the investment decision must be made in accordance with the plan documents.

The application of this analytic approach may be illustrated by considering two current issues in the social-investing debate. First, there has been considerable commentary suggesting that a plan fiduciary will find it easier under the law to exclude certain investments because of their supposed social deficiencies than to affirmatively select other investments because of their perceived social advantages. The argument is made that: exclusion is more likely to be permissible because the fiduciary is simply "crossing out one firm from a universe that has a huge number of options." 223

Although it will be difficult as a practical matter to establish financial loss when a fiduciary eliminates a limited number of investments from a large universe of acceptable alternatives, it makes relatively little difference from a legal perspective whether the fiduciary proceeds by a method of exclusion or inclusion. The critical questions are: first, whether the investments that the fiduciary is considering have the financial characteristics to satisfy the plan's

223 Social Investing: A Volatile Issue Surfaces, Penstons \& Investments, Oct. 23, 1978, at 24 (quoting Professor Roy A. Schotland). 
investment objectives, and second, whether the fiduciary's criteria for choosing or eliminating some investments within this acceptable universe are designed to further the retirement interests of the plan participants and beneficiaries. The use of a socially sensitive investment policy to guide the affirmative selection of investments is permissible so long as the investments are prudent and the policy is designed primarily to further the interests of the plan participants and beneficiaries. On the other hand, the statute appears to prohibit the exclusion of even a limited number of investments within the acceptable universe on the basis of self-interested goals such as benefiting the company or the union.

Of course, the number of investments excluded under the investment policy may be of some relevance in deciding whether that policy can be harmonized with the prudence and diversification requirements of the statute. When a socially dictated investment policy requires the exclusion of an entire category of investments, it may preclude the fiduciary from achieving one of the plan's investment objectives. For example, one study found that exclusion from the Standard and Poor's 500 of all companies with business interests in South Africa would eliminate all major multinational firms and essentially eliminate many major industries, such as computers, international oils, major chemicals, and automobiles. ${ }^{224}$ In these circumstances, a fiduciary's efforts to achieve appropriate diversification may be stymied. Another recent study of the market performance of the top ninety-nine institutional holdings concluded that those thirty-nine companies deemed "socially irresponsible" by the Corporate Data Exchange Study ${ }^{225}$ had performed slightly better over the past five years than the sixty presumably "responsible" companies.226 Without exploring the precise significance of these studies, it can be inferred that a broad exclusion policy may require the sacrifice of some element of safety or return. On the other hand, a veto of just a few stocks, such as that reportedly granted to the union in the Chrysler settlement, is not likely to preclude the fiduciary from locating equivalent investment opportunities. ${ }^{22 \tau}$

224 See Mares, supra note 10; So. African stock is dumped but no ill effects yet: Heritage, Pensions \& Investments, Nov. 5,1979 , at 6.

225 Corporate Data Exchange, Inc., Penston Investments: A Social Audit (1979). See note 15 supra.

226 Robert A. Levy of Computer Directions Advisors, Inc. found that 39 "bad guys" had produced an average gain of $83.5 \%$ over the past five years (exclusive of dividends) whereas the 60 other leading holdings had gained only $76.8 \%$ in the same period (exclusive of dividends). Social Investing could hurt fund performance: CDA Study, Pensions \& Investments, Nov. 19, 1979, at 35.

227 See note 14 supra. 
Once the prudence hurdle has been cleared, the policy must then be squared with the "solely in the interest" standard. As noted above, ${ }^{228}$ when dealing with a situation in which the benefit to plan participants is difficult to identify and yet no evidence of selfdealing appears to be involved, courts may well re-examine the prudence issue and, if satisfied that that standard is satisfied, elect not to force a "random choice" notion of selection.

A second area of controversy in the social-investing debate in which the legal framework of ERISA can provide guidance, is the voting of shares owned by the plan. As noted earlier, ${ }^{229}$ the fiduciary standards of ERISA section 404 apply to such activities on the part of plan fiduciaries. The prudence rule of section $404(a)(1)$ (B) prohibits the fiduciary from voting the shares in a way that would jeopardize either the safety or return of the plan's investments. The "solely in the interest" test of ERISA further proscribes any attempt by a fiduciary to use voting power to further the fiduciary's own interests. ${ }^{230}$

Apart from these constraints, however, the fiduciary probably has relatively broad discretion in voting the plan's shares. For example, corporate law recognizes that those who control corporations may choose to sacrifice immediate financial gain in the pursuit of a socially responsible policy that will yield good will or an improved business environment. ${ }^{231}$ As a practical matter, a plan fiduciary may be able to justify most of his votes on social issues with the explanation that the socially responsible course of conduct was in the best interests of the corporation and therefore protective of the financial health of the retirement fund. It would be only an extreme case when the use of voting influence could jeopardize the financial integrity of the underlying entity. ${ }^{232}$

228 See notes 99-147 supra \& accompanying text.

229 See text accompanying note 73 supra.

230 Cf. Blankenship v. Boyle, 329 F. Supp. 1089 (D.D.C.), stay denied per curiam, 447 F.2d 1280 (D.C. Cir. 1971), affd mem., 511 F.2d 447 (D.C. Cir. 1975 ) (trustees violated common-law fiduciary duty of loyalty by maintaining unnecesarily large cash deposits at a bank controlled by the union of which one trustee was president).

231 E.g., A.P. Smith Mfg. Co. v. Barlow, 13 N.J. 145, 98 A.2d 581, appeal dismissed, 346 U.S. 861 (1953) (donation to private university); Union Pacific Railroad Co. v. Trustees, Inc., 8 Utah 2d 101, 329 P.2d 398 (1958) (donation to private foundation); Kelly v. Bell, 254 A.2d 62 (Del. Ch. 1969) (payment in lieu of taxes to local governments). See generally 6A W. Fletcher, Cyclopedia of the Law of Pruate Corporations $\$ 2938$ (1968); Blumberg, Corporate Responsibility and the Social Crisis, 50 B.U. L. Rev. 157 (1970).

232 See 125 Conc. Rec. 5560 (daily ed. Jan. 24, 1979) (remarks of Sen. Williams):

Stressing once again that the ERISA fiduciary rules are designed to achieve a goal of great social importance, the supplying of retirement or deferred 
These examples illustrate the extent to which a fiduciary may consider social factors in discharging his duties under ERISA. No support can be found in the statutory standards for the proposition that a fiduciary must adopt a socially sensitive investment policy. ${ }^{233}$ The legislative history of ERISA suggests considerable congressional antagonism to any such requirement. Moreover, the highly structured allocation of investment responsibilities permitted by the Act, under which a trustee or investment manager is given only limited duties and powers with respect to a portion of the plan's portfolio, constitutes a serious barrier to any effort to vest the investment manager with responsibility for making social as well as financial judgments on behalf of all of the plan's participants. Finally, in light of the complexities inherent in defining social policies in the interest of participants, in setting priorities among those policies, and in developing criteria for measuring corporate compliance, it is difficult to imagine that a court would engraft on the otherwise mute language of the statute a judicial requirement that plan fiduciaries undertake such an arduous analysis.

If the analysis in this paper produces the sense of a restrictive legal environment, it is because ERISA and its legislative history suggest that significant barriers presently exist for fiduciaries who might use employee-benefit trust assets in order to achieve their own notions of socially desirable objectives. Although there appears to be some room within the legal framework of the statute for socially sensitive investment policies intended to promote the retirement interests of beneficiaries, ERISA appears to proscribe policies sacrificing financial comparability or promoting the interests of third parties in pursuit of some broader social objective. If this regulatory framework is found to be unsatisfactory, there may well be need for appropriate legislative change. Until that time, however, it ill behooves any fiduciary covered by the Act to embark on a program of social investing without first carefully analyzing the limitations contained in ERISA.

income and health and welfare benefits, there is no question in my mind that those rules permit the exercise of stock voting rights in a way that is consistent with other social concerns of the plan's participants and beneficiaries except in the rare case where such action would measurably impair the security of plan assets or adversely affect the plan's economically sound investment objectives.

${ }^{233}$ See Ferguson, Social Investing: An Advocate's Perspective, in EBRI, supra note 15 , at 93 . 